Nat. Hazards Earth Syst. Sci., 19, 1167-1187, 2019

https://doi.org/10.5194/nhess-19-1167-2019

(C) Author(s) 2019. This work is distributed under

the Creative Commons Attribution 4.0 License.

\title{
Towards multi-objective optimization of large-scale fluvial landscaping measures
}

\author{
Menno W. Straatsma ${ }^{1}$, Jan M. Fliervoet ${ }^{2}$, Johan A. H. Kabout ${ }^{3}$, Fedor Baart ${ }^{4}$, and Maarten G. Kleinhans ${ }^{1}$ \\ ${ }^{1}$ Faculty of Geosciences, Department of Physical Geography, Utrecht University, \\ P.O. Box 80115, 3508 TC, Utrecht, the Netherlands \\ ${ }^{2}$ Faculty of Science, Institute for Science, Innovation and Society, Radboud University, \\ P.O. Box 9010, 6500 GL, Nijmegen, the Netherlands \\ ${ }^{3}$ Arcadis Nederland B.V., Department Rivers, Coast and Sea, P.O. Box 220, 3800 AE, Amersfoort, the Netherlands \\ ${ }^{4}$ Deltares, Department Marine and Coastal Systems, P.O. Box 177, 2600 MH, Delft, the Netherlands
}

Correspondence: Menno W. Straatsma (m.w.straatsma@uu.nl)

Received: 31 August 2018 - Discussion started: 19 September 2018

Revised: 20 May 2019 - Accepted: 26 May 2019 - Published: 17 June 2019

\begin{abstract}
Adapting densely populated deltas to the combined impacts of climate change and socioeconomic developments presents a major challenge for their sustainable development in the 21 st century. Decisions for the adaptations require an overview of cost and benefits and the number of stakeholders involved, which can be used in stakeholder discussions. Therefore, we quantified the trade-offs of common measures to compensate for an increase in discharge and sea level rise on the basis of relevant, but inexhaustive, quantitative variables. We modeled the largest delta distributary of the Rhine River with adaptation scenarios driven by (1) the choice of seven measures, (2) the areas owned by the two largest stakeholders (LS) versus all stakeholders (AS) based on a priori stakeholder preferences, and (3) the ecological or hydraulic design principle. We evaluated measures by their efficiency in flood hazard reduction, potential biodiversity, number of stakeholders as a proxy for governance complexity, and measure implementation cost. We found that only floodplain lowering over the whole study area can offset the altered hydrodynamic boundary conditions; for all other measures, additional dike raising is required. LS areas comprise low hanging fruits for water level lowering due to the governance simplicity and hydraulic efficiency. Natural management of meadows (AS), after roughness smoothing and floodplain lowering, represents the optimum combination between potential biodiversity and flood hazard lowering, as it combines a high potential biodiversity with a relatively low hydrodynamic roughness. With this concept, we step up to
\end{abstract}

a multidisciplinary, quantitative multi-parametric, and multiobjective optimization and support the negotiations among stakeholders in the decision-making process.

\section{Introduction}

The World Economic Forum ranked extreme weather events, natural disasters, and failure of climate-change mitigation and adaptation in the top five risks in terms of likelihood as well as in terms of impact (WEF, 2018). Between 1995 and 2015 , floods made up $43 \%$ of the global occurrences of disasters within the category of extreme weather events (Wahlstrom and Guha-Sapir, 2015). For the future, Alfieri et al. (2016) showed that rising global temperatures will further increase the frequency and magnitudes of alluvial floods globally. In addition, coastal flood hazards are expected to increase due to sea level rise and changing storm wave and storm surge characteristics (Pardaens et al., 2011; de Winter and Ruessink, 2017) with high adaptation costs for coastal flood damage (Hinkel et al., 2014). Coastal deltas are particularly prone to flooding due to the possible coincidence of peak river discharges and storm surges. But even without a storm surge, the increased backwater effect due to higher sea levels affects water levels in delta distributaries during alluvial flood events. The ongoing urbanization in many deltas, combined with the associated land subsidence, further increases the exposure to floods (Giosan et al., 2014; Tessler et 
al., 2015). Flood protection measures (interventions) therefore need careful integration in the spatial planning of transport infrastructure and cities with a temporal horizon of 2100 and beyond. At the conceptual level, a strong point has been made for adaptation planning and nature-based solutions (Brown et al., 2014; Cheong et al., 2013), but the tools are missing to quickly apply these concepts at the delta scale.

Measures for flood hazard reductions should also take nature restoration into account. Rivers and deltas potentially have a high biodiversity because of the periodic flooding (Tockner and Stanford, 2002; Ward et al., 1999). However, land use change and population growth have degraded the biodiversity of floodplain habitats, especially in North America and Europe (Vorosmarty et al., 2010). River restoration efforts over the last three decades have tried to reverse degraded fluvial ecosystems (Bernhardt et al., 2005; Buijse et al., 2002), which were supported by the Clean Water Act in the USA and the Water Framework Directive in the EU (Hering et al., 2010). The combined efforts of projects with a joint objective of lowering the flood hazard and increasing biodiversity proved possible, although the biodiversity of protected and endangered species is still far below its potential (Straatsma et al., 2017).

River management has to combine varying objectives: flood safety is the primary goal in densely populated deltas, and navigation is often second. River restoration is increasingly included in industrialized countries to improve the biodiversity. A key challenge for environmental management is the number and diversity of the actors and sectors involved in the decision process because each has its own perceptions, interests, and resources (Robinson et al., 2011). Differences are fueled by the short temporal horizon for political decisions and the long-term effects of climate change but also by the perceived necessity of landscaping (i.e., terraforming; reconfiguration of the channel-floodplain geomorphology in US terms) measures to climate-proof the delta and societal resentment against large measures. Given the multitude of objectives and options for spatial planning, the need for decision support systems (DSSs) has long been recognized. Ideally, a DSS provides rational input, which could remove emotional objectives against specific adaptations, but we recognize that the personal threat experience also strongly drives actions to limit the flood risk (Grothmann and Reusswig, 2006). Newman et al. (2017) reviewed 101 DSSs for natural hazards, of which 19 focused on fluvial flood risk. Two included studies in the Netherlands: Hübner et al. (2009) developed the "Nature-oriented flood damage prevention", targeting regional water systems, whereas Schielen and Gijsbers (2003) created "DSS-large rivers", which was oriented towards the national to continental scale. Both DSSs required the manual implementation of landscaping measures in the accompanying geographic information system (GIS). To the best of our knowledge, none of the DSSs for fluvial flooding listed by Newman et al. (2017) enabled the semi-automatic planning of measures at the spatial scale of the river reach.
A semi-automatic system was presented by Straatsma and Kleinhans (2018), who used a rule-based system for the positioning and parameterization of measures. Coupling a DSS with semi-automated planning of mitigation measures could have additional value in the exploratory planning phase to provide all stakeholders with the efficiency of measures with respect to flood hazard reduction, costs, and biodiversity. No quantitative methodology exists that can combine the planning and parameterization of measures with a multidisciplinary evaluation.

The implementation of large-scale measures requires the alignment of governance at national, provincial, and municipal level and the involvement, compensation, or expropriation of different land owners. Land owners and actors involved in river management have diverse perspectives on, and incentives for, implementing river management measures based on socioeconomic, cultural, and land use characteristics (Rosenberg and Margerum, 2008; Verbrugge et al., 2017). New adaptation measures could therefore be implemented faster when fewer stakeholders are involved, provided they can agree about the type of measure. Therefore, it is necessary to understand land owner characteristics and their motivating factors to indicate the potential for implementing large-scale measures (Rosenberg and Margerum, 2008). Our objectives were to (1) quantify multifaceted trade-offs between landscaping measures to adapt a large delta distributary to sea level rise and increased river discharge while honoring ecological value and societal stakes and (2) include government complexity by positioning the measures in areas owned by the two largest stakeholders versus all stakeholders based on a priori preferences. The measures were parameterized based on nature restoration principles or maximizing flood conveyance capacity.

The decision on different possible interventions requires a multidisciplinary evaluation. Scientists can help to support this evaluation by transforming their data, models, and tools into quantities that can be used to objectively evaluate the different interventions. Here we show an example of how using advanced DSSs, that include cost estimates, as well as physical and ecological quantities, can help to move towards an evidence-based decision based on multidisciplinary performance metrics. We assessed the ability of 17 measures to compensate for increased discharge and rising sea levels in the Waal River in the Netherlands while improving the potential for biodiversity.

\section{Study area}

The study area is located in the Rhine delta (Fig. 1) in the Netherlands and comprises the main channel and embanked floodplains of the Waal River. The Waal is the main distributary of the Rhine River and is affected by expected changes in peak discharge as well as sea level rise. The three main concerns here are flood risk in view of global change, navigabil- 


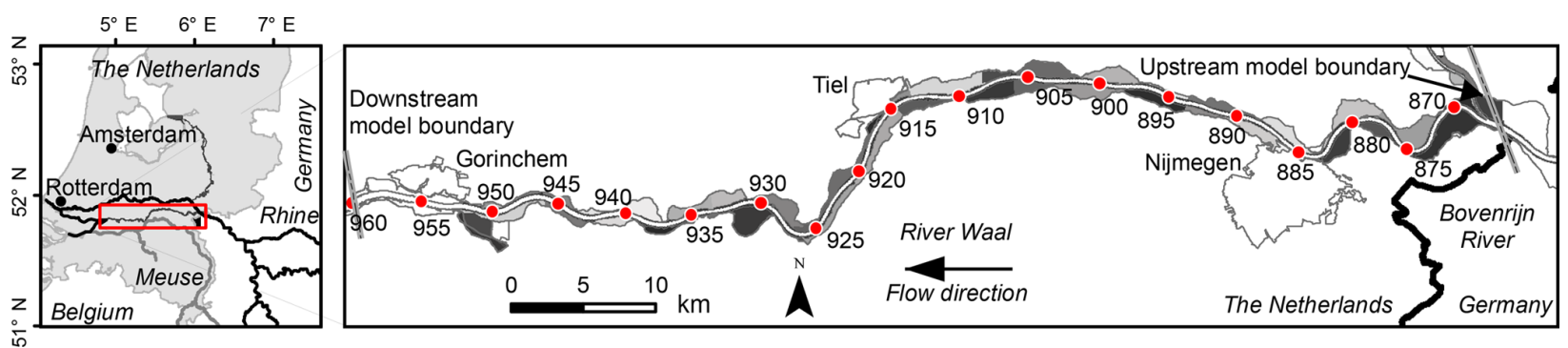

Figure 1. The river Waal, a river reach $85 \mathrm{~km}$ long between the Pannerden bifurcation near the Dutch-German border and Gorinchem, upstream of significant tidal influence. The center of the study area is located at $51^{\circ} 53^{\prime} \mathrm{N}$ and $5^{\circ} 37^{\prime} \mathrm{E}$. The greyscale differences show the 94 individual floodplain sections.

ity and ecosystem functioning. The study area spans a river reach $85 \mathrm{~km}$ long, with an average water surface gradient of $0.10 \mathrm{~m} \mathrm{~km}^{-1}$. The total area of the embanked floodplains amounts to $132 \mathrm{~km}^{2}$. Recent nature rehabilitation programs led to increased areas with herbaceous vegetation, shrubs, and forest (Koopman et al., 2018) in an area dominated by meadows. The design discharge for levee height is now set to $16000(\mathrm{Q} 16)$ and $10165 \mathrm{~m}^{3} \mathrm{~s}^{-1}$ for the Rhine branches and the Waal River, respectively. Q16 represents an average return period of 1250 years. Such a discharge is expected to give a $3.99 \mathrm{~m}$ water level above ordnance datum (+ OD) at the downstream end of the study area. The main channel, $250 \mathrm{~m}$ wide, is fixed in place by groynes (spur dikes, wing dikes) for the navigation and prevention of ice dams. It incises in its own deposits due to limited sediment supply from the catchment. Maintenance dredging in the insides of the bends is required to maintain the minimum navigable depth. The dredged material is dumped again in the deeper parts of the outer bend. Excavation of floodplain sediments occurs mainly in combination with interventions for flood hazard reduction. The groynes were partly lowered during the "Room for the River" project (Van Stokkom et al., 2005). In 2017, the new risk-based policy for flooding was accepted, which determines the local individual risk based on the design discharge and the failure probability of the flood protection structures (Van Alphen, 2016).

Flood risk management involves a number of public and private stakeholders (Table 1). It traditionally focused on the construction and maintenance of embankments (artificial levees), but recently the link with sustainable spatial planning has gained attention (Jong and Brink, 2017). Governmental responsibilities are divided over four levels, i.e., national, provincial, regional (water boards), and local (municipalities). The two largest land owners are Public Works and Water Management (PWWM; Rijkswaterstaat in Dutch), which owns 2889 ha, mostly consisting of the main channel and groyne fields, and the State Forestry Service (SFS; Staatsbosbeheer in Dutch), which owns 2813 ha that is mostly situated in the floodplains (Table 1). PWWM is the national water authority, and SFS is the national nature conservation organization; both are governmental organizations. The to- tal number of owners is 1233 between the embankments and 5512 within an additional $50 \mathrm{~m}$ buffer (Table 1) based on the cadastral database, which highlights the complexity of implementing area-wide measures.

The floodplain consists of 94 individually labeled areas on the left river bank (south) and the right bank, to which we will refer as floodplain sections (Fig. 1, grey shading). The area per stakeholder type differs strongly over the sections (Fig. 2a) as well as the number of owners (Fig. 2b). For example, the section at river kilometer $(\mathrm{rkm}) 870$ on river left (Fig. 2; 870-1) is called the Millingerwaard. It has a total surface area of 721 ha including the main channel, is largely owned by the State Forestry Service ( $428 \mathrm{ha}$ ), and has a total of 17 different owners, of which 12 are private citizens. Section 885_l (city of Nijmegen) contained the largest number of owners in the embanked area: 633 in total.

\section{Methods}

The rule-based planning and evaluation of measures required detailed input data (Table 2). Here, we describe the modeling tools plus their input data and the choices made within the hydrodynamic and landscaping scenarios.

\subsection{Modeling tools}

Here, we briefly describe the existing tools, RiverScape, Delft3D Flexible Mesh, and BIOSAFE, and elaborate on the cost assessment and the land ownership of all stakeholder groups. Reproduction, application, and extension of this work can also be conducted with other hydraulic models and other codes for biodiversity, while RiverScape has novel capabilities (Straatsma and Kleinhans, 2018).

\subsubsection{RiverScape: rule-based positioning and parameterization of measures}

In current river management practice, managers propose measures in the embanked floodplains together with landscape architects, engineers, policy advisors, and local stakeholders. Based on a sketch of the intervention, a GIS special- 
Table 1. Characteristics of nine land owner types involved in the maintenance of floodplains (based on Fliervoet and Van den Born, 2017). The remaining area is owned by foundations (66) and churches (20).

\begin{tabular}{|c|c|c|c|c|}
\hline Stakeholder & Organizational aim and/or responsibility & Governmental & $\begin{array}{r}\text { Total area } \\
\text { (ha) }\end{array}$ & $\begin{array}{r}\text { No. of } \\
\text { owners* }\end{array}$ \\
\hline $\begin{array}{l}\text { Public Works and } \\
\text { Water Management } \\
\text { (PWWM) }\end{array}$ & $\begin{array}{l}\text { Manage all activities in the floodplains that } \\
\text { influence water quality and quantity (flood } \\
\text { protection) on a national scale. }\end{array}$ & yes & 2889 & 1 \\
\hline $\begin{array}{l}\text { State Forestry } \\
\text { Service (SFS) }\end{array}$ & National nature conservation. & yes & 2813 & 1 \\
\hline Private land owners & $\begin{array}{l}\text { Citizens, farmers, and other local business } \\
\text { without a (private or limited) company. }\end{array}$ & no & 1122 & $964(4855)$ \\
\hline $\begin{array}{l}\text { Private and limited } \\
\text { companies }\end{array}$ & Create additional shareholder value. & no & 958 & 149 (319) \\
\hline $\begin{array}{l}\text { Sand, gravel, and } \\
\text { clay mining } \\
\text { industries }\end{array}$ & $\begin{array}{l}\text { Making profit and generating a long-term } \\
\text { perspective for the extraction of sand, } \\
\text { gravel, and clay from floodplains. }\end{array}$ & no & 767 & $13(15)$ \\
\hline Water board & $\begin{array}{l}\text { Responsible for dikes and levees (flood pro- } \\
\text { tection). }\end{array}$ & yes & 614 & $1(1)$ \\
\hline $\begin{array}{l}\text { Province founda- } \\
\text { tions, Geldersch and } \\
\text { Brabants Landschap }\end{array}$ & $\begin{array}{l}\text { Provincial organization aiming at the con- } \\
\text { servation of nature and cultural heritage. }\end{array}$ & no & 405 & $2(2)$ \\
\hline $\begin{array}{l}\text { Provincial } \\
\text { government }\end{array}$ & $\begin{array}{l}\text { Responsible authority for nature conserva- } \\
\text { tion goals, including the implementation of } \\
\text { the European Natura } 2000 \text { objectives on the } \\
\text { provincial scale. }\end{array}$ & yes & 366 & $1(1)$ \\
\hline Municipalities & $\begin{array}{l}\text { Responsible for local spatial planning: } \\
\text { regional development through balancing } \\
\text { economy, nature, recreation, and flood pro- } \\
\text { tection. }\end{array}$ & yes & 328 & $15(17)$ \\
\hline
\end{tabular}

* Number of owners between the main embankments per type of stakeholders ( embankments plus a $50 \mathrm{~m}$ buffer $($ sum $=5512)$.

Table 2. Overview of input datasets used for intervention planning and evaluation.

\begin{tabular}{|c|c|c|}
\hline Dataset & Derived data & Reference \\
\hline Baseline & River geometry, trachytopes & Scholten and Stout (2014) \\
\hline BAG-2015 & Building locations and type & BAG (2016) \\
\hline Cadastral map & Stakeholder type & $\begin{array}{l}\text { http://www.kadaster.nl/-/eigendomskaart-eigenarenkaart } \\
\text { (last access: } 28 \text { November 2016) }\end{array}$ \\
\hline Soil pollution map & Areas of polluted soil & Stienstra $(2011)$ \\
\hline Top10vector & Road location, type, and width & http://www.kadaster.nl/-/top10nl (last access: 20 November 2016) \\
\hline Ecotope map 2012 & Ecotopes, side channel location & Scholten and Stout (2013) \\
\hline
\end{tabular}

ist translates the position of the measure and the parameterization in terms of land cover and terrain height into layers of spatial data, for example with HEC-GeoRAS (Ackerman, 2011) or Baseline (Scholten and Stout, 2014). Both steps are time-consuming, and, therefore, often only a few scenarios are developed (Nardini and Pavan, 2012). For this study, we used RiverScape, a software tool for the rule-based position- ing and parameterization of flood hazard reduction measures. A detailed description of the tool is given by Straatsma and Kleinhans (2018). In brief, given a set of raster layers describing the hydrodynamic conditions at design discharge, the geometry, and the land cover, this tool proposes the location of seven different types of measures (Fig. 3), based on a set of rules for positioning and parameterization. The 


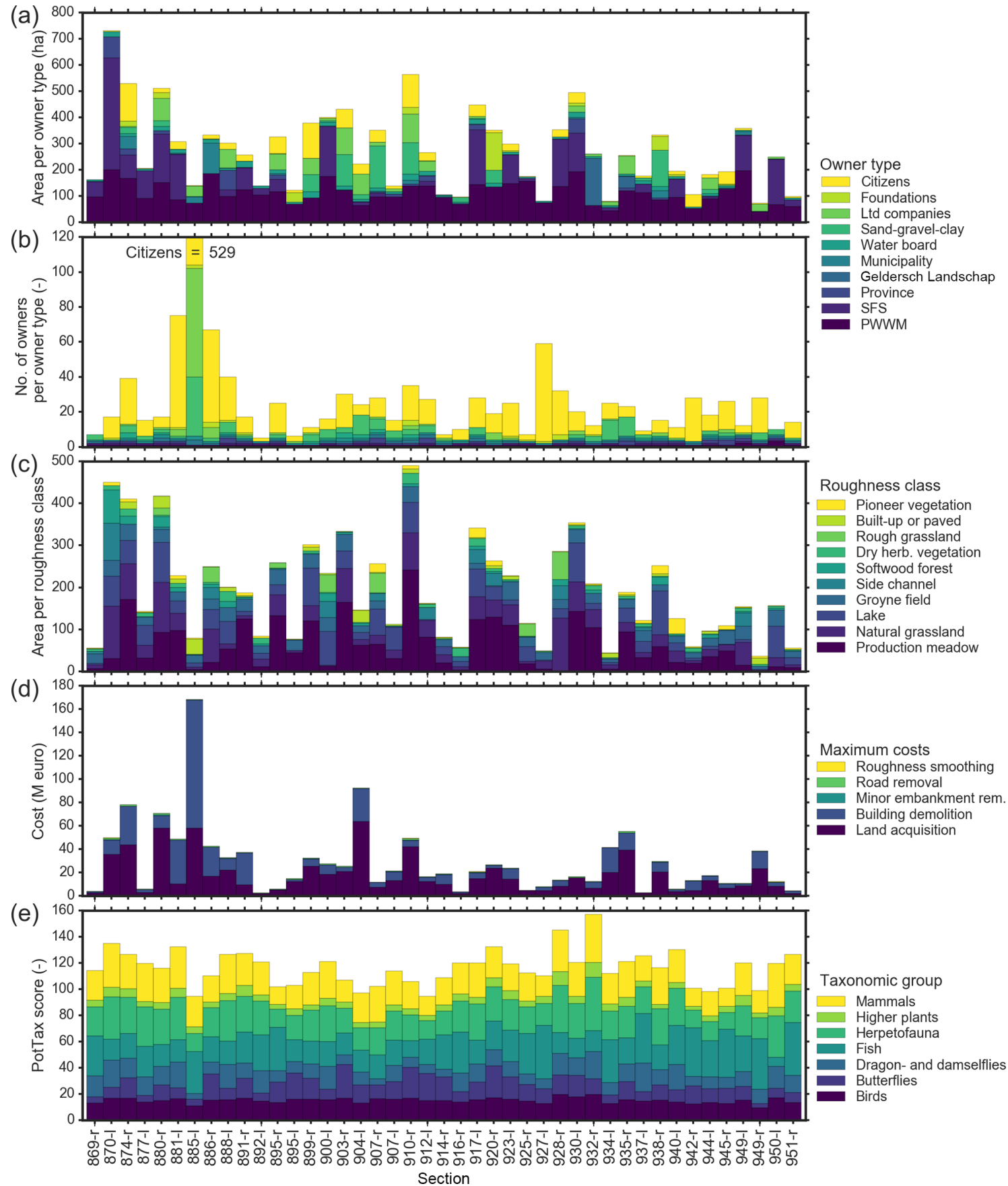

Figure 2. Overview of attributes of floodplain sections (Fig. 1). The sections are labeled by the mean river kilometer, followed by the "r" for river right and "-l" for river left: (a) surface area per type of owner (churches not shown), (b) number of owners per owner type, (c) surface area of the 10 dominant hydrodynamic roughness classes, (d) costs per item over the whole section in millions of euro (M euro), and (e) floodplain biodiversity scores per taxonomic group.

new bathymetry and the height of minor embankments (minor levee for the prevention of summer flooding of floodplain agricultural fields) and groynes (wing dikes, or spur dikes) are controlled by user-specified reference heights expressed as water levels at the river axis with a specific exceedance probability. The new land cover is given as an ecotope and roughness class. RiverScape was extended with a masking option to enable the application of the measures over arbitrary areas, in this case, the areas owned by specific stakeholder groups. Each measure is defined by seven raster layers (area, bathymetry, ecotopes, trachytopes (roughness class), groyne height, minor embankment height, and main embank- 


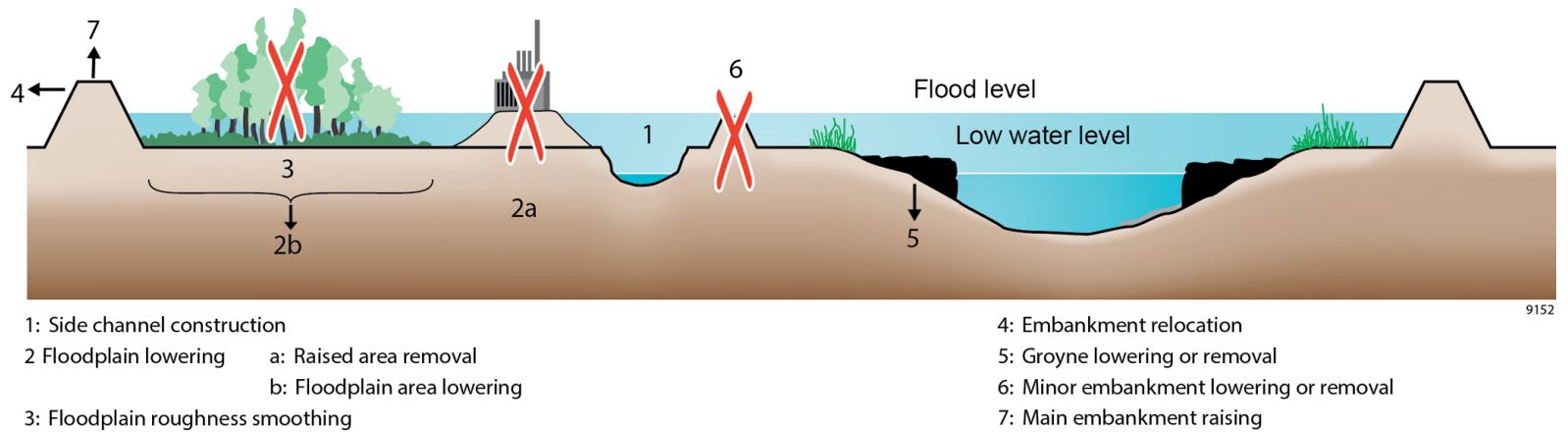

Figure 3. Typical landscaping measures implemented in this paper (figure after Middelkoop and Van Haselen, 1999).

ment height), together with the user settings. The generation of measures takes less than 2 min, which makes it a fast option for scenario development.

\subsubsection{Delft3D Flexible Mesh: hydrodynamics}

RiverScape was coupled to a calibrated 2-D hydrodynamic model. We used Delft3D Flexible Mesh (DFM), the opensource hydrodynamic model that is developed and maintained by Deltares (2016). The computational core of DFM solves the shallow water equations based on the finitevolume method on an unstructured grid (Kernkamp et al., 2011; UGRID Conventions, 2016). The computational mesh of the study area consisted of 71000 active cells between the main embankments. The DFM input files consisted of bathymetry, trachytopes, fixed weirs for groyne height and minor embankment height, thin dams for buildings and bridge pillars, and dry areas for embankment relocation. These files were updated with the RiverScape measure definition of each intervention following procedures described by Straatsma and Kleinhans (2018). The boundary conditions are specified by the upstream discharge and the downstream water level (Fig. 1). Only stationary discharges were simulated.

\subsubsection{BIOSAFE: potential biodiversity}

We applied the BIOSAFE model (De Nooij et al., 2004; Lenders et al., 2001; Straatsma et al., 2017) to evaluate the measures on the potential biodiversity for protected and endangered species that are representative of the fluvial environment. The BIOSAFE conceptual model comprises a set of links between riverine species and legal and policy documents for species protection on the one hand and links between species and ecotopes on the other hand. These two sets create a link between the legal domain and ecotopes via species. BIOSAFE calculates scores of potential biodiversity for seven taxonomic groups. The scores represent potential species presence based on habitat requirements, which were weighed by (1) the number of legal and policy documents assuming equal importance for all documents and (2) the sur- face area of associated ecotopes, and that are normalized by the area under consideration, enabling the comparison of the scores over floodplain sections with different sizes. In this study we calculated the PotTax, the potential biodiversity of protected and endangered species for each of the taxonomic groups (higher plants, dragonflies plus damselflies, butterflies, fish, herpetofauna, birds, and mammals). PotTax values were summed up into a single PotAll score for all groups together. PotTax and PotAll scores were calculated for each floodplain section (Figs. 1; 2e) separately and averaged over the whole study area for each scenario. Figure $2 \mathrm{e}$ shows the PotTax scores for the reference situation.

\subsubsection{Cost evaluation}

River restoration projects are costly, but costs are often reported in aggregated form over the whole project (Bernhardt et al., 2005). Ayres et al. (2014) compiled the available evidence of the cost of river restoration and showed that the costs varied strongly for a single type of measure but also that only a few of the cost estimates contained information on different cost items. They proposed a cost typology, which distinguished nonrecurring costs (planning, transaction, land acquisition, and other construction/investment costs) from recurring costs (annual maintenance and monitoring costs). In this study, we limited the scope to the nonrecurring costs required for the implementation of the measures. The data for the cost appraisal (Appendix A; S. Prins, unpublished data) should be interpreted as indicative, as neither the building contractor nor the client that orders the measure wants to share their valuation tables for fear of losing their position during negotiations. Recurring costs are generally an order of magnitude lower and depend on the land management after the implementation of the measure.

The preprocessing for the cost evaluation consisted of the information extraction from several sources to obtain the spatial distribution of the cost items. The so-called cost maps were subsequently overlaid with the measure definition. We used (1) the BAG-2015 database, a cadastral database for building locations and building types; (2) Top10vector, a vector-formatted geodatabase containing the roads' location, 
type, and width; (3) the ecotope map of 2012 for a simplified land cover; (4) the Baseline geodatabase for the position and length of groynes and minor and main embankments; and (5) the soil pollution map (Table 2 and references therein). Polluted soil is expected only in the top $1 \mathrm{~m}$ of the soil (Middelkoop, 2002) from sediment deposition in the floodplains. The ecotope map was used for the cost of roughness smoothing. Units of river kilometer were used to calculate the cost of dike raising. To calculate the nonrecurring costs, we determined the capital expenditures (CAPEX) for each measure. We are aware that additional operational expenditures (OPEX) increase the total cost over the lifetime of the measure and that different trade-offs could be found depending on the temporal horizon, but this is beyond the scope of this study. For each cost item, we mapped the unit cost in Euro per unit; the standard deviation is around 15\% of the unit price (Appendix A). The spatial distribution of the costs of smoothing, road removal, minor embankment removal, building acquisition and demolition, and land acquisition (Fig. 2d) indicates that the acquisition cost of land and buildings dominates the overall cost of measures.

The calculation of the cost per measure comprised the overlay of the cost maps with the measure definition. For side channel recreation and floodplain lowering, the unit costs of earthwork per cubic meter were added. The volume of earthwork depended on the measure settings and the existing topography. Postprocessing was required to correct for the use of data from different sources. For example, the ecotope map does not contain road information, but the cost for road removal should be equal to zero for a smoothing measure. No land acquisition costs are assumed for roughness lowering.

\subsubsection{Owner type and number of owners}

We used the cadastral map (http://www.kadaster.nl/-/ eigendomskaart-eigenarenkaart) to classify the owners into different types of stakeholders (Fig. 2a, b). The name of the entitled person of each parcel was processed with a set of rules to classify them into nine different stakeholder types listed in Table 1. In addition, we defined the type "foundations" and the remaining type "other", which consisted mainly of parcels owned by churches. PWWM and SFS were easily classified as they consisted only of a single or a few entitled owners. Sand, gravel, and clay companies were extracted by their specific names, e.g., WAAL BRICKS B.V. The number of owners was determined by counting the number of individual owners within the area of the measure or within each floodplain section (Fig. 2b) using vector overlay operations. The number of owners was used as a proxy for governance complexity because the area of the measure extent is owned by a person or organization, which requires (1) the alignment of the majority of the stakeholders with the measure and (2) expropriation of the other land owners. This process is more complex when many stakeholders are involved.

\subsection{Scenario development}

The modeling tools of Sect. 3.1 enabled the exploration of different adaptation scenarios with respect to changing hydrodynamic boundary conditions and adaptation measures. We used 17 measures (Table 3) for each of the three hydrodynamic scenarios. Trade-offs between flood safety, implementation cost, potential biodiversity, and number of stakeholders were quantified for each hydrodynamic scenario. The trade-offs consisted of the measures that represented the optimal combination of two variables and were represented as a line. The optimal measures were extracted from the convex hull of the measures' scores in the attribute space. No attempt was made to select a single optimal measure by means of minimizing an objective function because such techniques require weighing factors for the four aspects, and these are currently unknown. The weighing factors can also change quickly due to changing public opinions and political will, and they differ between stakeholders. Nonetheless, we highlight specific interventions as optima in the multidimensional parameter space.

\subsubsection{Hydrodynamics}

The hydrodynamic boundary conditions were given by the upstream river discharge and the downstream water level. The embankments have a flood protection standard for a flood (Q16) with a statistical return period of 1250 years (Silva et al., 2004). However, Q16 did not include the projected effects of climate change. The future design discharge of the river Rhine is uncertain. In policy documents, $18000 \mathrm{~m}^{3} \mathrm{~s}^{-1}$ (Q18) is used as the likely maximum discharge for the year 2100 based on climate change and (emergency) measures taken in Germany (Deltaprogramma, 2017). This value was based on an extensive study which combined a stochastic weather generator with a flood routing scheme (Hegnauer et al., 2014). Projections of increased discharge are based on intensification of precipitation extremes (van Pelt et al., 2012) and changes in runoff generation and flood routing (Hegnauer et al., 2014). We chose Q16 and Q18 as the upstream boundary conditions in the hydrodynamic model. Q18 translates to a discharge of $11435 \mathrm{~m}^{3} \mathrm{~s}^{-1}$ for the river Waal. Sea level rise (dh) was implemented as a $1.8 \mathrm{~m}$ additional setup of the downstream water level (dh1.8) for 2100. We did not take additional increase in water levels into account from storm setup on the North Sea. We chose a rise of $1.8 \mathrm{~m}$ as a high-end projection (RCP8.5) based on two probabilistic studies that included scenario and model uncertainty: Le Bars et al. (2017) reported a median rise of $1.84 \mathrm{~m}$ ( $95 \%$ confidence interval $=2.92 \mathrm{~m}$ ), which included the possibility of Antarctic ice sheet collapse (DeConto and Pollard, 2016), and De Winter and Ruessink (2017) reported a $2.5 \%$ exceedance probability for $\mathrm{dh}=1.5 \mathrm{~m}$ for the North Sea. With Q18 and dh1.8, a large part of possible future hydrodynamic conditions is covered. We ran DFM with three sets of 
Table 3. Overview of 17 landscaping scenarios: six measures, two locations based on stakeholders (all stakeholders and large estate owners), and two design principles (smooth and natural). All measures were evaluated for three sets of hydrodynamic boundary conditions (Q16_dh0.0, Q18_dh0.0, and Q18_dh1.8). The abbreviations are used in results' figures.

\begin{tabular}{llll}
\hline Measure type & Stakeholders* & $\begin{array}{l}\text { Design } \\
\text { principle }\end{array}$ & Abbreviation \\
\hline $\begin{array}{l}\text { Roughness lowering } \\
\text { Roughness lowering }\end{array}$ & All & natural & Smoothing_AS_natural \\
Roughness lowering & Large & nmooth & Smoothing_AS_smooth \\
Roughness lowering & Large & smooth & Smoothing_LS_natural \\
Side channel creation & All & natural & Sidechannel_AS_natural \\
Side channel creation & All & smooth & Sidechannel_AS_smooth \\
Side channel creation & Large & natural & Sidechannel_LS_natural \\
Side channel creation & Large & smooth & Sidechannel_LS_smooth \\
Floodplain lowering & All & natural & Lowering_AS_natural \\
Floodplain lowering & All & smooth & Lowering_AS_smooth \\
Floodplain lowering & Large & natural & Lowering_LS_natural \\
Floodplain lowering & Large & smooth & Lowering_LS_smooth \\
Minor embankment lowering & All & NA & Minemblowering_AS \\
Minor embankment lowering & Large & NA & Minemblowering_LS \\
Groyne lowering & All & NA & Groynelowering_AS \\
Groyne lowering & Large & NA & Groynelowering_LS \\
Dike raising & All & NA & Dikeraising_AS \\
\hline
\end{tabular}

NA: not applicable. * Abbreviated to "AS" for all stakeholders and to "LS" for large stakeholders, i.e., Public Works Department and State Forestry Service.

boundary conditions, labeled as "Q16_dh0.0", "Q18_dh0.0", and "Q18_dh1.8" for all measures. We compared the resulting water levels at the river axis for each measure with the modeled reference water levels of Q16_dh0.0 without any measure.

\subsubsection{Location: stakeholder involvement}

The options for landscaping measures for flood safety and river restoration by far exceed the two options to change hydrodynamic boundary conditions. The evaluation of all these options in terms of flood hazard, biodiversity, and costs is very time-consuming to carry out using preexisting software. The multitude of possible scenarios is driven by the responsible authorities and the number of stakeholders, their land ownership, and their preferred land use and legal permissions. At the same time, the perceived urgency to reduce the flood risk, the available budget, and political will also affect the choice for measures and the speed of implementation, although all stakeholders agree about flood safety as the number one priority. We simplified and summarized the stakeholders' preferences for specific measures based on their organizational objectives and responsibilities (Table 1) in order to derive a manageable set of scenarios for landscaping measures (Table 3). The stakeholders' preferences (Table 4) were based on Table 1, literature (Fliervoet and van den Born, 2017; Fliervoet et al., 2013), and expert judgement.

The directorate for Public Works and Water Management (PWWM) is the largest landowner (Table 1). They are the responsible authority for the flood protection objectives together with the water boards. Therefore, both are in favor of measures that improve the flood protection levels, especially on their own lands, such as roughness smoothing, floodplain lowering, and groyne lowering (Table 4). Although many side channels were constructed in the Room for the River program to realize flood protection and nature objectives, the PWWM does not have a clear preference for side channels because of high maintenance costs and increased sedimentation in the navigation channel (Van Vuren et al., 2015).

The State Forestry Service aims to develop more natural (unregulated) river systems by giving more room to natural erosion and sedimentation processes, in line with the vision of "self-regulating nature" (Stanford et al., 1996; Ward et al., 2001). This vision became a source of information for the Dutch ecological rehabilitation programs of the Rhine branches and Meuse River (Buijs, 2009), and it addresses measures which create a more dynamic floodplain environment, such as the construction of a side channel or lowering of the floodplains (Table 4).

The provincial governments are responsible for maintaining and developing nature in the floodplains since the decentralization in 2014 from the Ministry of Economic Affairs. They plan and implement EU Natura 2000 objectives, based on European legislation, and they allocate subsidies for nature conservation. This may require changes in land use, which are in turn regulated by the municipalities. Although the provinces are the nature authority, they are in favor of measures that have multiple objectives, such as constructing 
Table 4. Simplified stakeholder preferences for different measures.

\begin{tabular}{|c|c|c|c|c|c|c|c|c|c|}
\hline Stakeholder type & $\begin{array}{l}\text { Public Works } \\
\text { and Water } \\
\text { Management }\end{array}$ & $\begin{array}{l}\text { State } \\
\text { Forestry } \\
\text { Service }\end{array}$ & $\begin{array}{l}\text { Private } \\
\text { land } \\
\text { owners }\end{array}$ & Company & $\begin{array}{l}\text { Mining } \\
\text { companies }\end{array}$ & $\begin{array}{l}\text { Water } \\
\text { board }\end{array}$ & $\begin{array}{l}\text { Province } \\
\text { foundations }\end{array}$ & $\begin{array}{l}\text { Provincial } \\
\text { government }\end{array}$ & $\begin{array}{l}\text { Municipa- } \\
\text { lities }\end{array}$ \\
\hline Side channel construction & 0 & + & 0 & - & $+^{\mathrm{b}}$ & 0 & 0 & $+^{\mathrm{a}}$ & 0 \\
\hline Roughness smoothing & + & - & $+^{\mathrm{c}}$ & 0 & 0 & 0 & $+^{\mathrm{d}}$ & 0 & 0 \\
\hline Floodplain lowering & + & + & $-c$ & - & $+^{b}$ & 0 & - & $+^{\mathrm{a}}$ & 0 \\
\hline Dike raising & 0 & 0 & 0 & 0 & $+^{b}$ & $+\mathrm{g}$ & 0 & 0 & 0 \\
\hline
\end{tabular}

Legend is as follows: + denotes those in favor of implementing measure on own properties; 0 denotes those with no clear opinion or no mandate; - denotes those against measure. Notes are given as follows. ${ }^{\mathrm{a}}$ In the case flood safety and spatial quality are combined, e.g., in the Room for the River program. ${ }^{\mathrm{b}}$ Extraction of sand, clay, or gravel. ${ }^{\mathrm{c}}$ Agricultural function. ${ }^{\mathrm{d}}$ To maintain cultural landscape. ${ }^{\mathrm{e}}$ Responsible for groynes. ${ }^{\mathrm{f}}$ Responsible for minor embankments. ${ }^{\mathrm{g}}$ Responsible for, and owner of, the main embankment.

a side channel or lowering a floodplain. Both measures have the opportunity to reconcile the objectives of flood protection and restoring nature in the floodplains.

The water boards are responsible for, and the owners of, the dikes and minor embankments. They prefer the following measures: minor embankment lowering and dike raising. Private land owners (especially farmers) and companies are often against measures such as minor embankment lowering and floodplain lowering, due to the increased flooding frequency of their land, which negatively affects their activities. The sand, gravel, and clay mining industries are often in favor of measures that lead to the excavation of soil in the floodplains. Finally, the province foundations ("Geldersch and Brabants Landschap") are aiming at the conservation of nature and cultural heritage, such as braid hedges (woven growing hedges used as parcel delineation) or fortresses in the floodplains. These foundations perceive minor embankment lowering and floodplain lowering negatively and roughness smoothing positively where a "park-like" landscape is concerned (Fliervoet et al., 2013).

Stakeholder involvement and their land ownership determined the locations where the measures were positioned. The first option for the location of measures was the combination of the large stakeholders (LS) that own large areas, being PWWM and SFS, based on their a priori preferences of measures. They own $56 \%$ of the whole study area together (Table 1) and $31 \%$ of the groyne field plus floodplain area. They agree with floodplain lowering as a possible measure, disagree with roughness smoothing, and do not disagree with the other measures (Table 4). SFS opposes roughness smoothing because it opposes their vision of self-regulating nature, except when it is performed within the context of cyclic floodplain rejuvenation. Given the large area owned by these two stakeholders only, they can relatively easily implement the different measures on their own property, even though they pursue different ultimate objectives. The second option was that the measures could be implemented on the property of all stakeholders (AS). This means that all 1233 stakeholders would need to endorse the measure or be compensated. Given the different objectives of the stakeholders, this can only be realized after a major disaster when the urgency is high. Although this is not the current state in the Netherlands, we still include it because of the changing hydrodynamic boundary conditions over time. This gave two location scenarios: LS and AS.

\subsubsection{Measure type and design principle}

Six adaptation measures were implemented in the groyne field and the existing floodplains (Fig. 3); measures in the main channel and the areas protected by the main embankments were not considered. The design principle of the measure affected the choices made within RiverScape with respect to the new land cover and the cross-sectional shape of new side channels. The first option, labeled as "smooth", was to optimize the conveyance capacity of the floodplain, whereas the second option, labeled as "natural", included ecological qualities as favored by SFS and the provincial government. No difference between smooth and natural designs was implemented for minor embankment lowering, groyne lowering, and dike raising because the land use is assumed to remain identical.

We parameterized the measures in RiverScape (Straatsma and Kleinhans, 2018) with the following settings. Firstly, roughness lowering (smoothing) was applied over $100 \%$ of the location (LS or AS) and resulted in production meadow (ecotope UG-2 and trachytope 1201) for the smooth scenario and natural grassland (ecotope UG-1 and trachytope 1202) in the natural scenario. Production meadow has a slightly lower roughness than natural grassland, with Chézy coefficients of 38 and $35 \mathrm{~m}^{1 / 2} \mathrm{~s}^{-1}$ at $3 \mathrm{~m}$ water depth, respectively (Van Velzen et al., 2003). However, the potential biodiversity of natural grassland is twice as high. Secondly, floodplain lowering led to excavation of the terrain to the local height that is inundated $50 \mathrm{~d} \mathrm{yr}^{-1}$ for both the natural and the smooth option. Production meadow was assigned to the measure area in the smooth option and natural grassland in the natural 
option, similar to roughness lowering. Thirdly, natural and smooth side channels differed in their cross-sectional shape and depth. Both were connected to the main channel only at the downstream end. We choose a width of $75 \mathrm{~m}$, a depth of $2.5 \mathrm{~m}$, and lateral slopes of 1 to 3 for smooth side channels. Natural side channels were parameterized with a $50 \mathrm{~m}$ width, a $1 \mathrm{~m}$ depth, and lateral slopes of 1 to 7 . Ecotopes for deep and shallow side channels were assigned, which translates into the same trachytope. Finally, minor embankments and groynes were lowered to the water level which exceeded 50 and $150 \mathrm{~d} \mathrm{yr}^{-1}$, respectively. The main embankment was raised by $1 \mathrm{~m}$ over the whole study area. Embankment relocation was excluded.

\section{Results}

In order to quantify the trade-offs, we will first describe individual components to gain a detailed understanding. The hydrodynamic evaluation is given most attention because flood safety represents the top priority for all stakeholders.

\subsection{Measure positioning and hydrodynamic effects}

The measures were positioned in the areas owned by the large stakeholders (PWWM and SFS; Fig. 4), or over the whole area. The fraction of the surface area owned by the large stakeholders varied strongly between the floodplain sections. The main channel and the groyne field are completely owned by the PWWM, whereas SFS owns the majority of specific floodplains sections, such as around 900-1 and 928-r (Fig. 1).

The different hydrodynamic boundary conditions (Fig. 5a, b) led to spatial variation in the water levels. Q18_dh0.0 gives a $0.33 \mathrm{~m}$ increase in water levels at the downstream boundary, which increased rapidly in the upstream direction to a maximum of $0.76 \mathrm{~m}$ at $\mathrm{rkm} 880$. Conversely, the Q18_dh1.8 scenario gave the highest water level increase downstream: $2.12 \mathrm{~m}$. In the upstream direction, the differences decline due to the reduced impact of the backwater effect further upstream, with a minimum increase of $0.76 \mathrm{~m}$ at $\mathrm{rkm} 868$, the model boundary on the upstream end. Two measures give lower water levels than in the reference situation in the Q18_dh0.0 and Q18_dh1.8 scenario, which is an over-dimensioning of the measures.

The effects of the measures differed strongly between the type of measure and the location (Fig. 6, left column). We compared the simulated water level with the reference situation (Q16_dh0.0, without measures) for all hydrodynamic and landscaping scenarios to see to what extent the measures can lower the flood hazard or mitigate the changing hydrodynamic conditions. Groyne lowering mainly affected the upstream area, with a maximum lowering of $0.06 \mathrm{~m}$. Minor embankment lowering gave a maximum lowering of 0.07 and $0.11 \mathrm{~m}$ for large stakeholders (LS) and all stakeholders (AS), respectively. Roughness lowering was more effective, with a maximum of $0.21 \mathrm{~m}$ for AS_smooth and a minimum of $0.09 \mathrm{~m}$ for LS_natural. LS_smooth and AS_natural both reach $0.14 \mathrm{~m}$ water level lowering. The largest effects and the largest differences between the measure parameterizations were observed for side channels and floodplain lowering. Side channels showed a sequence of backwater curves from the individual measures, with a maximum lowering of $0.38 \mathrm{~m}$ for AS_smooth and $0.34 \mathrm{~m}$ for AS_natural (Fig. 6) in the upper part of the Waal, which is due to the combined effects of all channels and the higher water surface slope. Floodplain lowering gave the maximum water level reductions, which ranged between $0.62 \mathrm{~m}$ for lowering_LS_natural and $1.37 \mathrm{~m}$ for lowering_AS_smooth.

The water level lowering per measure was almost equal between the hydrodynamic scenarios. The correlation coefficient between water level lowering exceeded 0.999 between Q16_dh0.0, Q18_dh0.0, and Q18_dh1.8. The similarity in lowering can be observed in Fig. 6 by comparing the differences in water level between the reference ( $y=0$ in the left column and the grey lines in the middle and right column) and the colored lines representing the measures. This difference is nearly identical between the three columns.

The measure efficiency in compensating the changing hydrodynamic conditions (Fig. 6 middle and right columns) showed that only floodplain lowering was able to lower water levels below the reference situation. Lowering was more efficient upstream, with the zero crossing at rkm 933 and 920 for AS_smooth in Q18_dh0.0 and Q18_dh1.8, respectively (Fig. 6). The other measures did not lower the water levels below the reference. All measures were more efficient in water level lowering in the upper reach. On average, the lowering was 2.2 times larger upstream (rkm 868-894) than downstream (rkm 919-945), ranging from 1.1 times for smoothing_AS_natural to 4.4 times for minemblowering_LS. Floodplain lowering at the locations of all stakeholders could compensate for the additional discharge (Q18_dh0.0) both upstream and downstream, but for Q18_dh1.8 this measure only suffices upstream (Fig. 6 bottom right panel).

\subsection{Effects on potential biodiversity and implementation costs}

The overall changes in PotAll varied strongly between the scenarios and between the floodplain sections (Fig. 7). Floodplain smoothing gave the largest positive and negative differences, with positive changes related to the natural scenario and negative changes to the smooth scenario. The largest positive changes represent floodplain sections that largely consisted of agricultural fields and production meadows, which were converted to natural grassland (e.g., 895-1 and 912-1 in Figs. 1 and 7). Conversely, the smooth scenario led to the largest decline in PotAll, due to the conversion of ecologically valuable ecotopes to production meadow. Most notable is 932-r for which the PotAll value dropped from 157 in the 


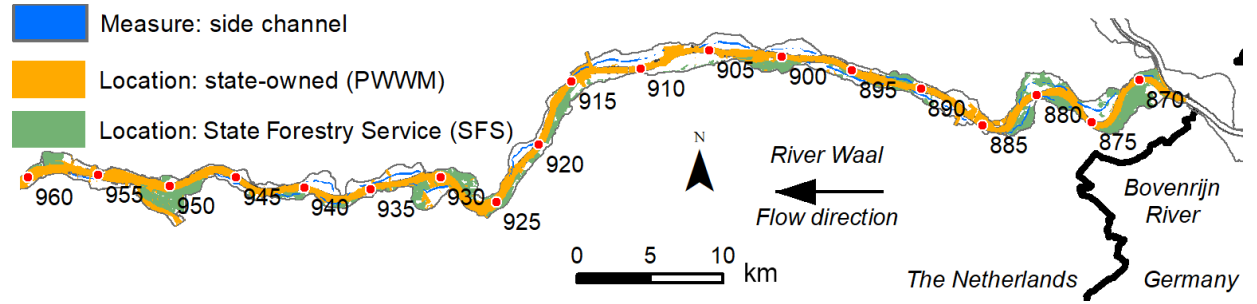

Figure 4. Location of the two largest stakeholder, the state (Public Works and Water Management) and the State Forestry Service (SFS). The other public and private stakeholders own the remaining areas in white. The location of the side channels represents the smooth option for the whole area (AS). Water flows right to left. Measures are implemented over the whole reach, independent of the reference water level being exceeded.
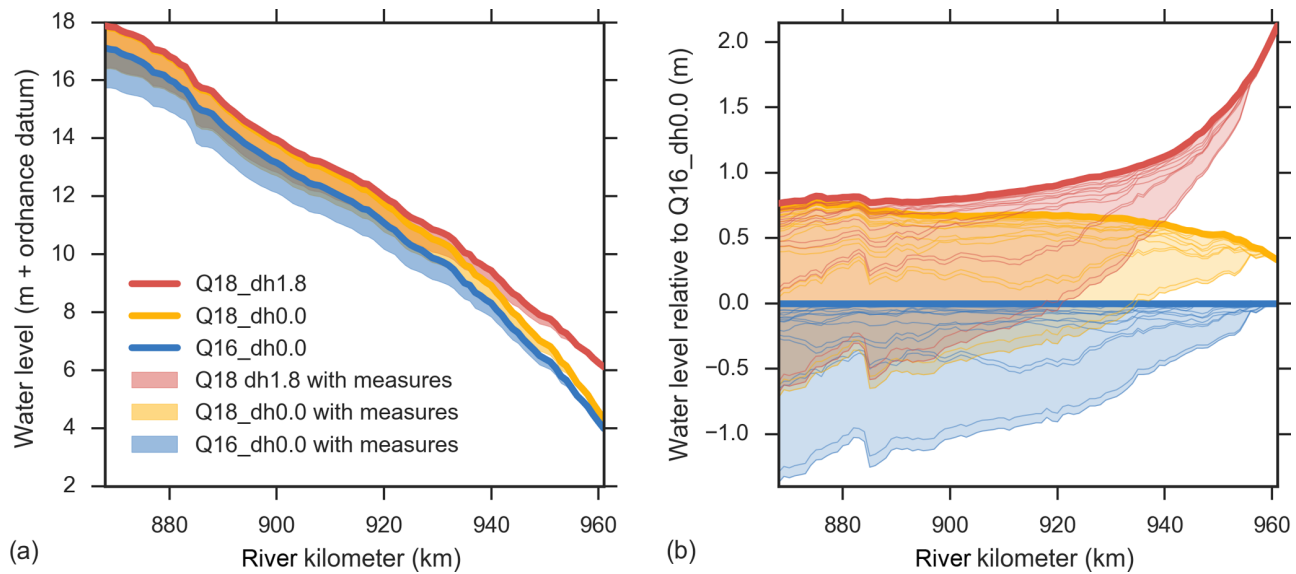

Figure 5. (a) Absolute water level for the three hydrodynamic sets of boundary conditions (solid lines) and the effects of the implemented measures for Q16_dh0.0 and Q18_dh1.8 in the shaded areas. (b) Changes in water level relative to the reference situation, Q16_dh0.0 without measures. The thick lines represent the relative changes without any measures; the thin lines represent the 16 different measures for each set of boundary conditions. Water flows left to right.

reference situation to 41 and 67 after the implementation of smoothing_AS_smooth and lowering_AS_smooth, respectively. The effects of side channels on PotAll scores were positive for all scenarios, except for section 932-r. However the differences were smaller compared to floodplain lowering and roughness smoothing (Fig. 7) due to the smaller spatial extent of the side channels.

The PotAll scores increase from the floodplain lowering and roughness smoothing when the area is managed as a moist natural grassland after the measure has been carried out. This holds even for floodplain sections that already had a high PotAll value in the reference situation. The increase represents the difference in potential biodiversity between natural moist grasslands and the dominant production-oriented land cover in floodplains along many northwest European rivers.

The implementation costs varied strongly between the measures, ranging from EUR 1.7 billion for lowering_AS to EUR 2 million for floodplain smoothing (Fig. 8). The largest costs are inferred by the acquisition of buildings and land, and the costs of forest removal and mowing for floodplain smoothing are very low. The costs of raising the dikes represent a $1 \mathrm{~m}$ increase in dike height. The fraction of the costs for building removal is $9 \%$ for the LS case and $35 \%$ for the AS case, indicating that the LS have relatively few built-up areas.

\subsection{Quantification of trade-offs for climate adaptation measures}

The combination of the water level lowering, changes in PotAll, the implementation costs, and the number of stakeholders involved provided insight into the trade-offs of the different scenarios (Fig. 9). As a data reduction step, we aggregated values over the whole study area. The water level lowering was averaged over the entire river reach, even if the water level was below the reference, as in the Q16_dh0.0 hydrodynamic scenario. PotAll scores were averaged over all floodplain sections, and total costs are presented. The total number of individual stakeholders involved was calculated over the measure area. The lower left corner of each panel (Fig. 9) represents utopia, the optimal combination of the two criteria, and the wide grey line links the measures that repre- 


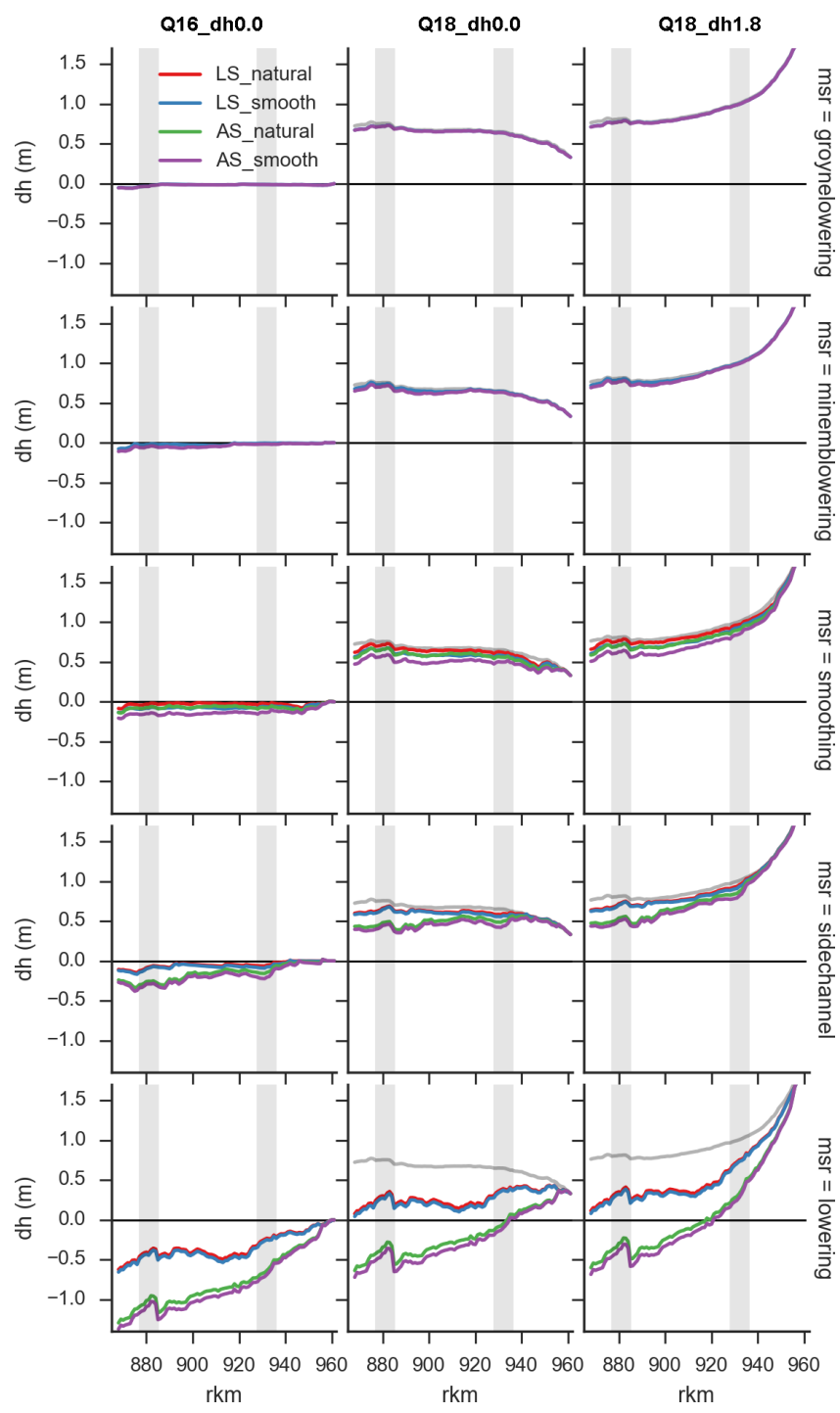

Figure 6. Water level changes $(\mathrm{dh})$ at the river axis relative to the reference situation (Q16_dh0.0). The water levels of Q18_dh0.0 and Q18_dh1.8 are shown as grey lines. Water flows left to right, with the upper and lower area highlighted as grey vertical bands; see text for statistics. Measure (msr) type is indicated on the right. The grey lines in the middle and right column represent the effects of boundary conditions only.

sent the trade-off. Note that the PotAll axes were reversed to visualize utopia in the lower left corner. Dike raising by $1 \mathrm{~m}$ was visualized as a water level lowering of $1 \mathrm{~m}$ for visualization purposes.

We considered a low number of stakeholders favorable for fast implementation of a measure. The number of stakeholders involved in measures has an optimum in water level lowering for dike raising $(n=948)$, lowering_LS, and sidechannels_LS (both $n=2$ ) (Fig. 9a). Smoothing_AS_natural is closest to dystopia, with 1200 stakeholders and only a small reduction in water level, which highlights the problems of managing the floodplain roughness. However, legislation exists that makes roughness lowering obligatory in areas with high conveyance capacity.

The trade-offs between PotAll and water level lowering consisted of dike raising, lowering_AS_natural, and smoothing_AS_natural (Fig. 9b). The mean reference value of PotAll is 112 as represented by dike raising and the "reference". All measures above this reference line $($ PotAll $=112)$ have a lower PotAll score (note the reversed axis) and a decreased potential biodiversity. The natural and smooth scenarios for floodplain lowering and smoothing show up as paired points above and below the reference line with a similar water level lowering. For example, the mean potential biodiversity can be increased to 166 for floodplain smoothing over the whole area and natural grassland as land cover (smoothing_AS_natural), but it can also be decreased to 70 by applying production meadow as the land cover (smoothing AS_smooth). The mean difference in water level reduction between these two measures is less than $0.08 \mathrm{~m}$ due to the similarity in vegetation roughness between these trachytopes.

Cost-effectiveness measures in terms of water level lowering consisted of dike raising and smoothing_AS_smooth (Fig. 9c), which are the two traditional methods of flood risk prevention in the Netherlands. Floodplain lowering_LS touches the grey optimum line and keeps an intermediate position. Lowering_AS is almost 3 times more expensive than dike raising and does not lower the water levels much in the lower reaches (Fig. 6). All roughness smoothing measures have low implementation costs, but it should be noted that they will differ in productivity after implementation.

Improving the PotAll scores was easiest in terms of number of stakeholders with smoothing_LS_natural, which was followed by smoothing_AS_natural, even though 1200 stakeholders were involved (Fig. 9d). The reference situation is also on the optimum line because zero stakeholders were involved. These measures also represent the cheapest way to increase PotAll values (Fig. 9f). The optimum in the number of stakeholders against total costs is represented by groyne lowering, minor embankment lowering, and smoothing at the LS locations. These points are not obvious in the plot (Fig. 9e); they only show up after zooming in on the lower left corner. The reference situation was ignored because it does not represent a measure.

\section{Discussion}

The flood protection structures and the land use in the delta are driven and constrained by three main needs: flood risk, socioeconomics, and ecology, as protected by national and European law. In this paper, we quantified the trade-offs between 17 landscaping measures to adapt a large delta distributary to increased flood hazards from sea level rise and increased river discharge, and we showed the effects of gover- 


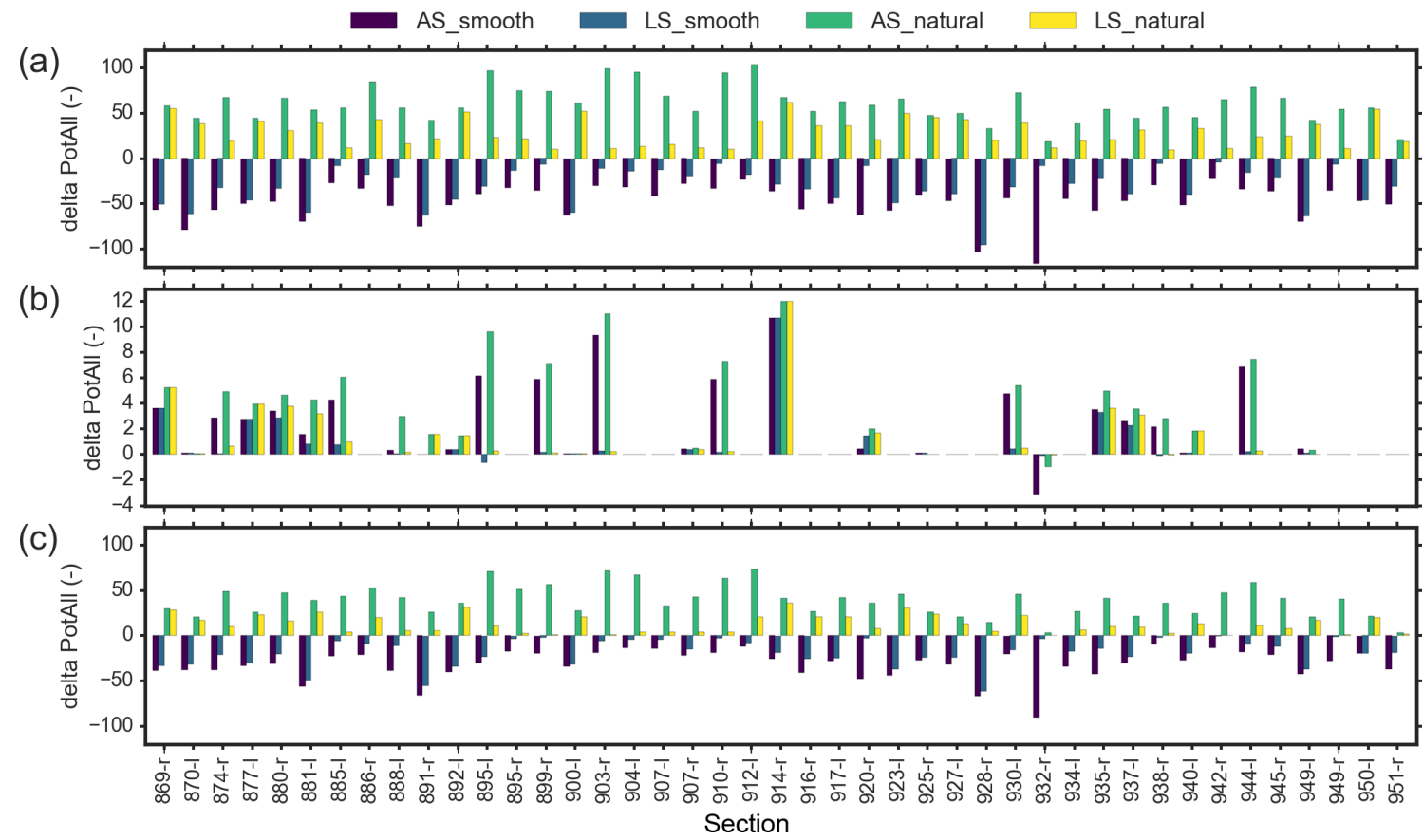

Figure 7. Changes in PotAll scores per floodplain section for three measure types: (a) smoothing (roughness lowering), (b) side channels, and (c) floodplain lowering. Note the different vertical scale in panel (b).

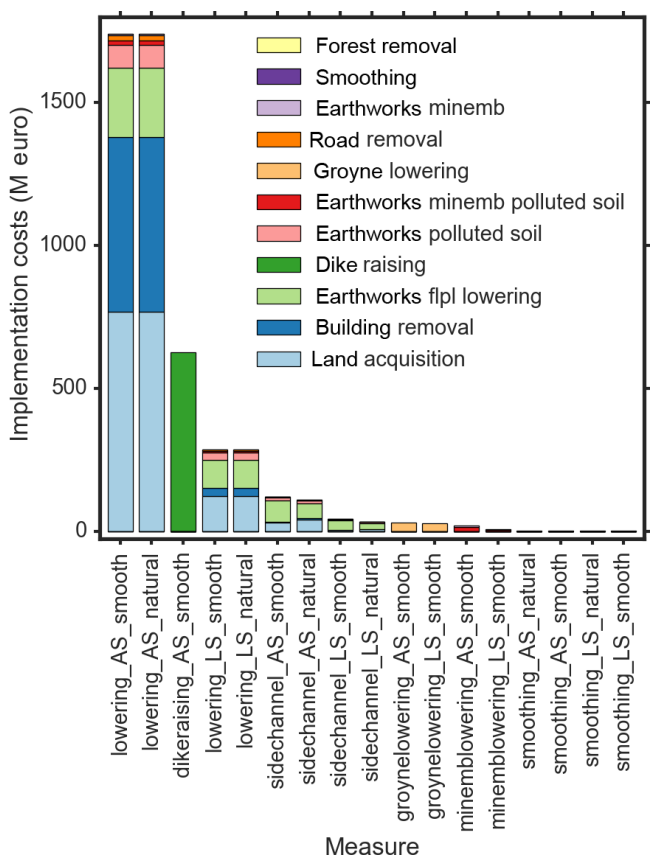

Figure 8. Comparison of costs between scenarios in millions of euro (M euro).

nance complexity using land ownership and stakeholder preferences as a proxy. Our methodology suits the early stages of the planning process as it provides an overview of possible measures to adapt to climate change and the associated capital expenditures, plus the hydrodynamic and ecologic effects. Compared to other DSSs targeted at intervention planning (Hübner et al., 2009; Schielen and Gijsbers, 2003), we added the option for automatic positioning and parameterization of measures over arbitrary areas, costs, and the number of stakeholders. Our modular structure enables more evaluation criteria to be added. In the final stages of intervention planning, additional weighting of interventions is required in practice using a multi-criteria analysis. Changing the weights will alter the trade-offs between the evaluation parameters. For example, the single objective of flood hazard reduction would rank embankment raising, floodplain lowering, side channels, and roughness smoothing as top priorities, whereas conversion to natural grassland would be favored from the river restoration perspective of protecting threatened and endangered species.

The quantification of the trade-offs showed clear optima in the parameter spaces between water level lowering, potential biodiversity, implementation costs, and the number of stakeholders (Fig. 9). It confirmed the cost-effectiveness of dike raising and roughness smoothing, which are the measures that represent the traditional flood protection strategy. We showed that flood safety can only be maintained by raising the dikes by $1 \mathrm{~m}$ or excavating the floodplains over the entire area, as long as only measures inside the embanked floodplains are considered (Fig. 6). Large-scale embankment relocation can also lower water levels by a meter (Straatsma and Kleinhans, 2018). None of these options are politically accepted at the moment, given the recent comple- 

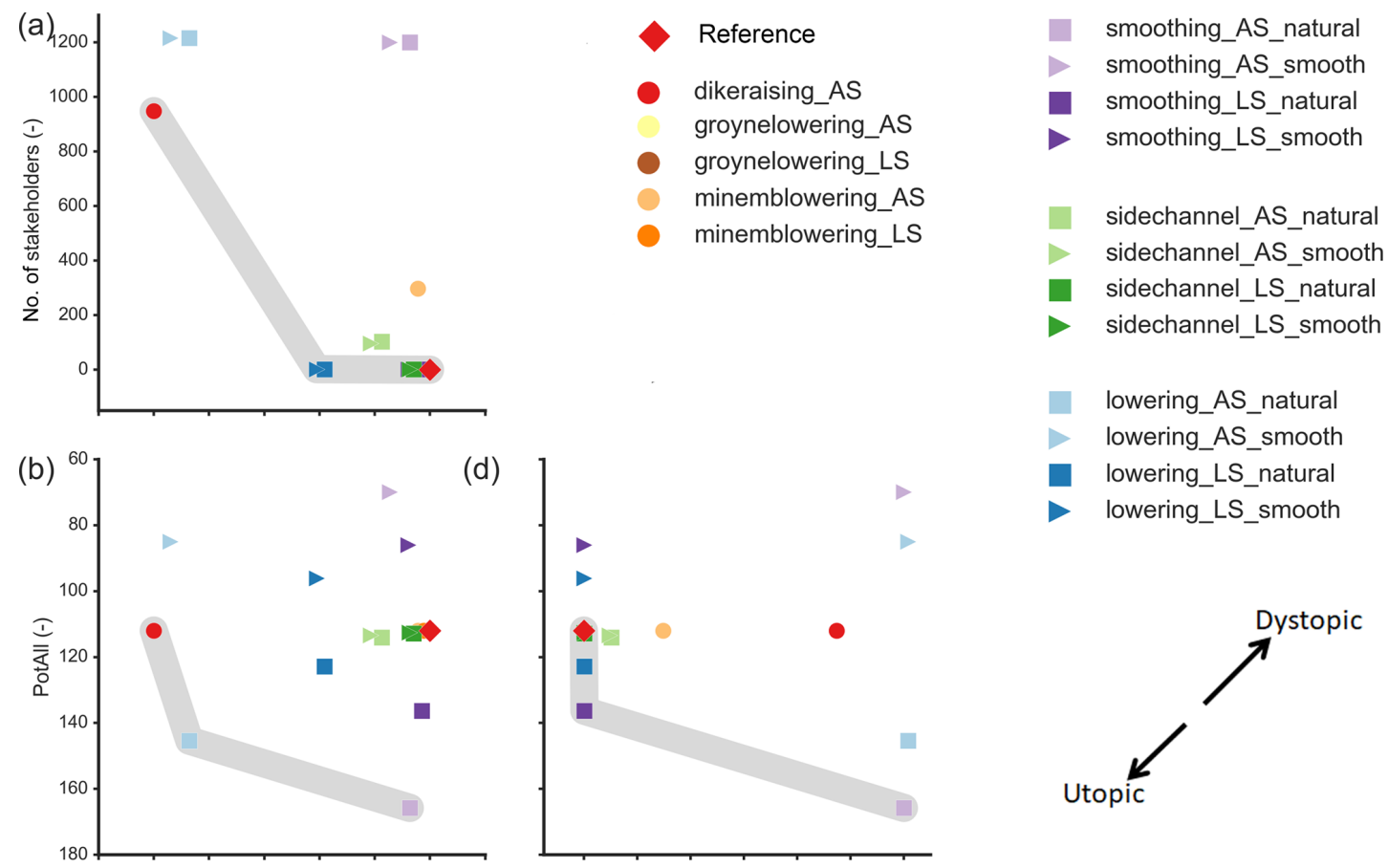

(d)
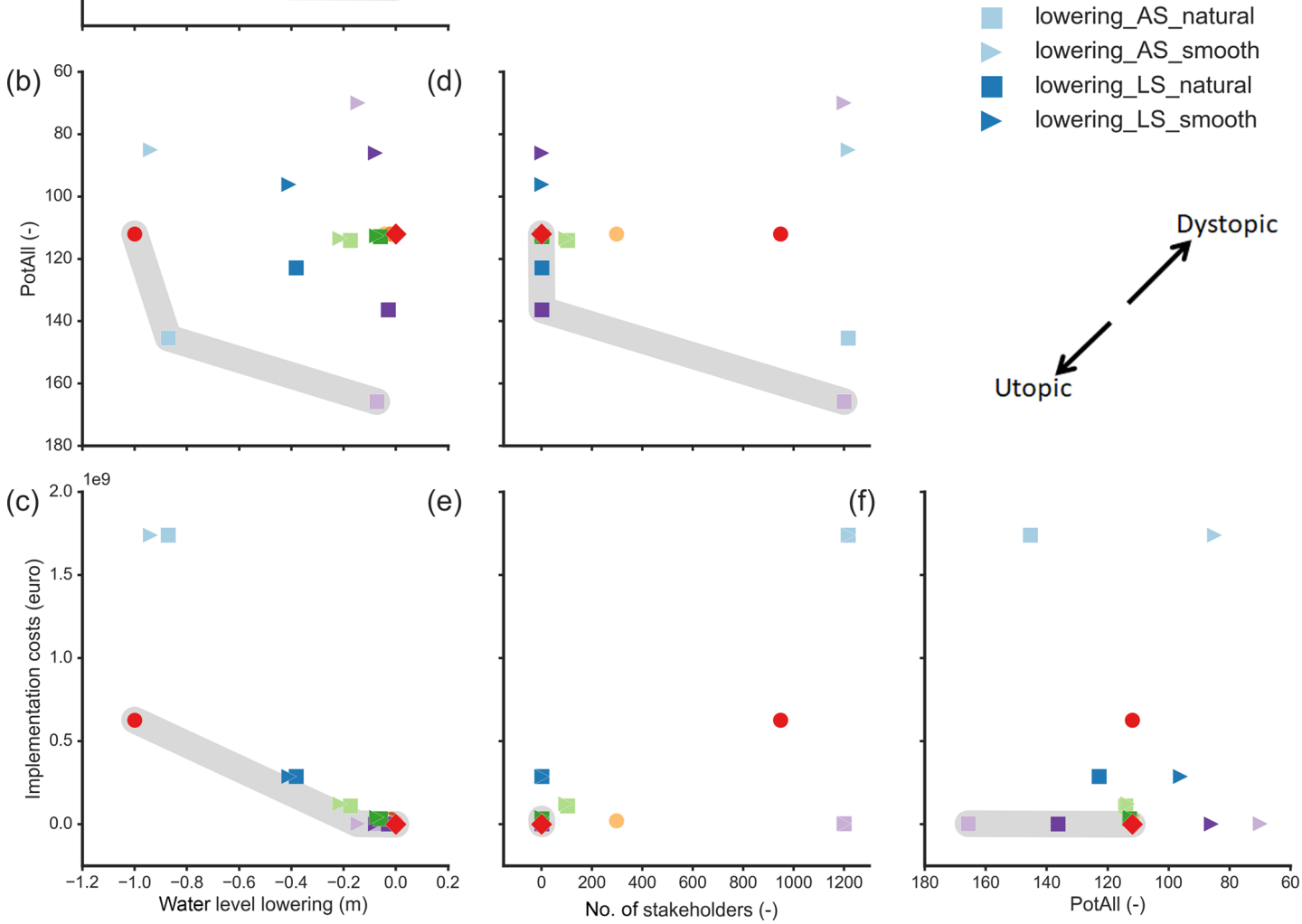

Figure 9. Scatterplot matrix of the main criteria for intervention planning. The grey areas indicate the optimum combination of criteria for each panel. Similar colors represent one type of measure, and shading represents the difference in location. The two design principles are visualized, with a rectangle for natural and a triangle for smooth. The diamond represents the reference situation.

tion of the so-called Room for the River program. This program aimed at increasing the design discharge from 15000 to $16000 \mathrm{~m}^{3} \mathrm{~s}^{-1}$, and now river managers focus on efficient maintenance of the floodplains (Fliervoet and van den Born, 2017). However, given the large uncertainties in sea level rise and river discharge, the focus may quickly change.

The quantified trade-offs led to new insights in the potential effectiveness of the two largest stakeholders for water level lowering and biodiversity. Measures in the areas owned by the two largest stakeholders lowered the water levels more effectively per unit area because these stakeholders own the areas with the highest conveyance capacity. The parameter space between potential biodiversity and implementation cost gave a surprising quasi-horizontal trade-off, with the highest biodiversity scores for roughness smooth- ing and conversion to natural grassland at a low cost, which is followed by the reference situation. This highlights natural grassland as a good candidate for multi-objective optimization on biodiversity increase and flood hazard decrease because the difference in water level lowering was small. Such an intervention would not have shown up in the typical cost-effectiveness of measures. The addition of biodiversity scores to the evaluation enables simultaneous evaluation of measures for the EU Flood Directive and Water Framework Directive.

The owner-specific areas for measures served as a proxy for the complexity of implementation in terms of governance because more owners means longer implementation times. It created insight into the possible contributions of the stakeholders in large-scale interventions. Decision-making in in- 
tegrated river management is more complex and dynamic in reality because of the number and diversity of stakeholders and sectors involved, each with their own views, interests, and resources (Mostert et al., 2007; Robinson et al., 2011). The outcome of stakeholder sessions, the preferred measure, will vary depending on the individuals involved in the debate, which possibly leads to a suboptimal solution. We determined the stakeholder preferences a priori (Table 4) and used their preferences and land ownership to position and parameterize the measures. Our findings suggest that despite varying views of stakeholders, it is useful to model stakeholder preferences based on factors such as their role, responsibility, and visions for floodplain management. This provides valuable knowledge for stakeholders prior to or during engagement in multi-stakeholder platforms from the perspective of social learning (Borowski, 2010). The scores per land owner group (LS and AS) provide the stakeholders with a better understanding of the possibilities and limitations of the solution space. It has the potential to accelerate the decision-making processes because the stakeholder preferences and their interdependence are concisely visualized and immediately apparent with our methodology. Mutual recognition of interdependence and a shared understanding of the possible solutions are essential elements in the decision-making process (Ansell and Gash, 2008).

To the best of our knowledge, stakeholder sessions have not been repeated to assess their variation in outcomes because they are time-consuming. Alternatively, the variation in stakeholder processes could be modeled using game theory, or agent-based models, but this is still in its infancy: Samsura et al. (2010) used game theory to extract the strategic decisions used by stakeholders, Strager and Rosenberger (2006) integrated GIS with stakeholders preferences in a spatial multicriteria analysis to identify high priority areas for land conservation, and Becu et al. (2003) created an agent-based system of a catchment in northern Thailand, including farmers' individual decisions. They attributed the agents with the availability of water, land, cash, and labor force and focussed on decisions made by farmers, instead of including the preferences made by other stakeholders. These studies generally focussed on catchment scale and require substantial adaptation before they can be applied in the management of large lowland rivers. Our a priori preferences could serve as input for these types of models, and their output could be used to drive the planning of measures.

In this paper, we used water level lowering as the starting point for the positioning of the measures. An alternative to the owner-specific areas of measure locations could be ecological or financial considerations. Ecological optimization would involve ranking the ecotopes according to their potential biodiversity. High-ranking ecotopes should be left untouched, whereas ecotopes with a low potential biodiversity are suitable candidates for river restoration measures. Additional weighting of the ranking could be the hydrodynamic roughness or specific taxonomic groups. Likewise, the loca- tions with high economic value could be left untouched to lower the costs of implementation. All these choices could be implemented as alternatives in the rule-based positioning and parameterization of measures.

The limited capacity within the floodplain area to lower the flood hazard points to the need to create more space for the river and robust measures for additional discharge (Q18) and sea level rise (dh1.8). Our results are useful for developing an integrated river management plan because we provided large-scale boundaries for decision-making at the scale of a river reach. The results can help to argue in favor of establishing multi-stakeholder platforms, such as river basin organizations, collaborative watershed partnerships, stewardship councils (in Dutch Waardschap), and "collaborative superagencies" (Fliervoet and van den Born, 2017; Jaspers, 2003; Pratt Miles, 2013; Verbrugge et al., 2017). With such collaborative structures, the major problem of fragmentation in terms of the number of land owners (Table 1, Fig. 9) could potentially be overcome.

Our methods were limited to the implementation of the measures and the effects on the peak water levels. Several extensions would create additional value for decision support. Firstly, extending flood hazard to flood risk of the protected land would provide insight into the costs of the measures in relation to the avoided losses in the case of inundation of the protected land. For this, the failure probability of the embankment should be assessed (Marijnissen et al., 2019) as part of a full flood risk assessment (Vrijling, 2001). Secondly, the altered flow patterns from the measures will give a morphologic response over time in the floodplain and in the main channel. Increased floodplain inundation affects the sediment deposition, with a mean sedimentation rate of $0.13 \mathrm{~mm} \mathrm{~d}^{-1}$ inundation for the floodplains and $2 \mathrm{~mm} \mathrm{~d}^{-1}$ inundation at the entrance of fast aggrading secondary channels (Baptist et al., 2004). Geerling et al. (2008) found a deposition rate of $3.7 \mathrm{~cm} \mathrm{yr}^{-1}$ for a lowered floodplain next to the main channel. The increasing floodplain elevation reduces the conveyance capacity and limits the longevity of the measure. For the main channel, opposite effects are projected: the Rhine delta has a reduced sediment supply due to the storage in upstream reservoirs for hydropower, which led to erosion of the main channel over the last decades (Frings et al., 2009). For the future, Sloff et al. (2014) predicted a main channel erosion of $0.25 \mathrm{~m}$ in the lower reach and $0.4 \mathrm{~m}$ sedimentation in the middle reach of the Waal, based on a 2-D morphological study spanning the period 2015 to 2055 . We assumed that the $1.8 \mathrm{~m}$ sea level rise translated into a $1.8 \mathrm{~m}$ rise of the downstream boundary condition and ignored the long-term morphological changes. Under natural conditions, the bathymetry would follow the rising sea level, but the results of Sloff et al. (2014) justify our assumption. Thirdly, vegetation management strongly affects the development of the hydrodynamic roughness. If the land is left fallow, vegetation succession will lead to herbaceous vegetation, shrubs, and floodplain forest after 5, 10, and 30 years, respectively, 
leading to a maximum increase in water level of $0.6 \mathrm{~m}$ for the IJssel distributary of the Rhine (Makaske et al., 2011). The succession positively affects the biodiversity, with a maximum increase of around $10 \%$ after 30 years. BIOSAFE needs to be updated to include these succession stages, as no ecotope succession model is currently available, and more detailed models (Asaeda et al., 2014; Sanjaya and Asaeda, 2017; van Oorschot et al., 2018; Camporeale et al., 2013) can not yet be linked to BIOSAFE. Fourthly, compensation of land owners that have increased inundation of their land due to the removal of minor embankments could be included just like avoided damage from lower exposure to flood risk in a full cost-benefit analysis. See Mechler and Bouwer (2015) and Di Baldassarre et al. (2015) for further discussion on risk management. Finally, we assumed that all measures are implemented instantaneously, whereas the timing could be made dependent on updated sea level rise projections to optimize the measures under uncertainty and avoid unnecessary costs (Postek et al., 2018; Kind, 2014). These potential extensions were beyond the scope of this paper.

\section{Conclusions}

Adapting large and densely populated deltas to changing hydrodynamic conditions is a daunting task, especially since both river restoration and socioeconomic developments compete for space, which prevents a single-objective solution. Careful spatial planning with stakeholder involvement should benefit from the integrated assessment of possible alternatives. We presented a rule-based method for the implementation and evaluation of landscaping measures, which was used to evaluate 17 scenarios based on the type of measure, the number of stakeholders involved, and ecological design principles. We found that (1) the traditional measures of flood hazard reduction in the Netherlands, dike raising and roughness lowering, represent the most cost-effective solutions; (2) using natural grassland as the land cover after roughness smoothing and floodplain lowering provides an optimum between improved biodiversity and water level lowering; (3) the two largest stakeholders could effectively lower flood levels as they own $31 \%$ of the groyne field plus floodplain, but the water level lowering from measures in these locations accounted for $34 \%$ to $54 \%$ of the lowering due to measures in the whole study area; and (4) only floodplain lowering over the whole area can compensate for the increased discharge and sea level rise at the costs of EUR 1.74 billion and the involvement of 1200 stakeholders.
Our method and its application provide decision makers and local stakeholders with (1) a wide range of measures that either requires the two largest or all of the owners in the area and (2) a standardized quantification of the trade-offs between water level lowering, ecology, and implementation costs. No single measure ranked highest on all attributes, underlining the wickedness of the problem. Our approach contrasts with the detailed analyses carried out in typical practice of river management, which normally considers a single floodplain section at a time due to the governance complexity. For these sections detailed plans are made in cooperation with stakeholders. Our setup enables fast exploration of pathways at the scale of a whole river reach, which can be adjusted by changing the rules for positioning and parameterization of the measures. The method can be transported to other regions, such as the Elbe, Mississippi, and Mekong rivers, and upscaled to the entire delta to support sustainable land use planning. Extensions of the method are required to include morphological changes, recurring costs, timing of measures, cost-benefit assessment, and vegetation succession. We argue that our results provide a common ground for any stakeholder meeting, which increases mutual understanding. Application in real-life stakeholder sessions is required to prove this point. The benefit of our approach lies in the large scale of the measures and the multiple criteria used in the evaluation, which enable higher-quality and more transparent planning with long time horizons. It also shows the future challenges and normative choices that need to be made.

Flood hazard management is embedded in a larger framework of river management as guided by international legislation (e.g., EU Flood Directive and Water Framework Directive). To achieve societal impact and adjust to changing boundary conditions, we need evidence-based and quantitative trade-offs to weigh the different stakes in society. With our approach, we are moving away from the traditional hydraulics-only analyses and towards multidisciplinary, multi-parametric, multi-objective optimizations for supporting the negotiations among stakeholders in the decision-making process.

Data availability. The data used in this paper are not publicly accessible due to limitations on the hydrodynamic model input data. However, the authors can be contacted by email (m.w.straatsma@uu.nl) for assistance in acquiring data access and acknowledgement. 


\section{Appendix A}

Table A1. Nonrecurring costs of measure implementation in unit prices. The unit prices represent the 2015 price level and exclude VAT and indirect costs for engineering, design, and unexpected costs. "kEUR" denotes EUR 1000.

\begin{tabular}{|c|c|c|c|c|}
\hline Category & $\begin{array}{l}\text { Cost item } \\
\text { per unit }\end{array}$ & $\begin{array}{r}\text { Price } \\
\text { standard } \\
\text { deviation }\end{array}$ & Price & Unit \\
\hline \multirow[t]{12}{*}{ Real estate } & Acquisition & & & \\
\hline & Agricultural area & 6.7 & 0.8 & $\mathrm{EUR} \mathrm{m}^{-2}$ \\
\hline & Nature areas & 1.2 & 0.2 & EUR m $^{-2}$ \\
\hline & Water areas & 0.8 & 0.1 & EUR m $^{-2}$ \\
\hline & Built-up areas & 190 & 50 & EUR $^{-2}$ \\
\hline & Individual house & 500 & 120 & kEUR per piece \\
\hline & Farms & 900 & 220 & kEUR per piece \\
\hline & Business & 1400 & 330 & kEUR per piece \\
\hline & Demolition & & & \\
\hline & Individual house & 20 & 3 & kEUR per piece \\
\hline & Farm & 40 & 6 & kEUR per piece \\
\hline & Business & 120 & 20 & kEUR per piece \\
\hline \multirow[t]{12}{*}{ Earthwork } & Floodplain lowering & & & \\
\hline & Storage at $25 \mathrm{~km}$ & 7.2 & 1 & EUR m $^{-3}$ \\
\hline & Additional cost of polluted soil & 10.2 & 3.4 & $\mathrm{EUR} \mathrm{m}^{-3}$ \\
\hline & Earthwork floodplain lowering, local usage & 3.1 & 0.8 & $\mathrm{EUR} \mathrm{m}^{-3}$ \\
\hline & Side channel & & & \\
\hline & Storage at $25 \mathrm{~km}$ & 8.1 & 1.2 & EUR m $^{-3}$ \\
\hline & Additional cost of polluted soil & 10.2 & 3.4 & EUR m $^{-3}$ \\
\hline & Earthwork floodplain lowering, local usage & 3.1 & 0.8 & $\mathrm{EUR} \mathrm{m}^{-3}$ \\
\hline & Minor embankment & & & \\
\hline & Storage at $25 \mathrm{~km}$ & 6.9 & 1 & EUR m $^{-3}$ \\
\hline & Additional cost of polluted soil & 10.2 & 3.4 & $\mathrm{EUR} \mathrm{m}^{-3}$ \\
\hline & Earthwork floodplain lowering, local usage & 1.9 & 0.5 & $\mathrm{EUR} \mathrm{m}^{-3}$ \\
\hline \multirow{5}{*}{$\begin{array}{l}\text { Roads and } \\
\text { bridges }\end{array}$} & Removal & & & \\
\hline & Bike lane removal, incl. dumping/recycling & 14 & 1 & EUR m $^{-2}$ \\
\hline & Road removal, incl. dumping/recycling & 27 & 3 & EUR m $^{-2}$ \\
\hline & Bike lane construction (width $<2$ m) & 28 & 3 & $\mathrm{EUR} \mathrm{m}^{-2}$ \\
\hline & Road construction (width $<7 \mathrm{~m}$ ) & 50 & 10 & $\mathrm{EUR} \mathrm{m}^{-2}$ \\
\hline \multirow{4}{*}{$\begin{array}{l}\text { Roughness } \\
\text { smoothing }\end{array}$} & Removal & & & \\
\hline & Grass mowing and removal & 540 & 170 & EUR ha ${ }^{-1}$ \\
\hline & Herbaceous vegetation mowing and removal & 810 & 270 & EUR ha ${ }^{-1}$ \\
\hline & Forest clearing and removal & 1330 & 440 & EUR ha $^{-1}$ \\
\hline \multirow[t]{3}{*}{ Groynes } & Lowering and conversion & & & \\
\hline & Groyne lowering & 650 & 170 & $\mathrm{EUR} \mathrm{m}^{-1}$ \\
\hline & Conversion to longitudinal training dam & 1900 & 390 & $\mathrm{EUR} \mathrm{m}^{-1}$ \\
\hline \multirow[t]{3}{*}{ Dikes } & Raising by one meter & & & \\
\hline & Upstream of river kilometer 933 & 3500 & 700 & $\mathrm{kEUR} \mathrm{km}^{-1}$ \\
\hline & Downstream of river kilometer 933 & 3600 & 700 & $\mathrm{kEUR} \mathrm{km}^{-1}$ \\
\hline
\end{tabular}


Author contributions. The authors' contributions varied between the following four categories. The contributions to conception and design were MWS $30 \%$, MGK $20 \%$, JMF $20 \%$, JAHK $15 \%$, and FB $15 \%$; contributions to data collection were MWS $80 \%$ and JMF $20 \%$; contributions to data analysis and conclusions were MWS $70 \%$, MGK $20 \%$, and JMF $10 \%$; and the contributions to the paper preparation were MWS $60 \%$, MGK $10 \%$, JMF $10 \%$, JAHK $10 \%$, and FB $10 \%$.

Competing interests. The authors declare that they have no conflict of interest.

Special issue statement. This article is part of the special issue "Flood risk assessment and management". It is a result of the EGU General Assembly 2018, Vienna, Austria, 8-13 April 2018.

Acknowledgements. This research is part of the research programme RiverCare, supported by the domain Applied and Engineering Sciences (AES), which is part of the Netherlands Organization for Scientific Research (NWO), and which is partly funded by the Ministry of Economic Affairs under the Perspective Programme. We thank Mitja Brilly and Holger Sandberg plus the two anonymous reviewers for their feedback, which significantly improved the paper.

Financial support. This research has been supported by the NWOTTW (grant no. P12-14).

Review statement. This paper was edited by Cristina Prieto and reviewed by Mitja Brilly and two anonymous referees.

\section{References}

Ackerman, C. T.: HEC-GeoRAS, GIS tools for support of HECRAS using ArcGIS, USGS, Davis, USA, CACPD-83, 242, 2011.

Alfieri, L., Bisselink, B., Dottori, F., Naumann, G., Roo, A., Salamon, P., Wyser, K., and Feyen, L.: Global projections of river flood risk in a warmer world, Earth's Future, 5, 171-182, https://doi.org/10.1002/2016ef000485, 2016.

Ansell, C. and Gash, A.: Collaborative Governance in Theory and Practice, J. Publ. Adm. Res. Theor., 18, 543-571, https://doi.org/10.1093/jopart/mum032, 2008.

Asaeda, T., Rashid, M. H., and Abu Bakar, R.: Dynamic Modelling of Soil Nitrogen Budget and Vegetation Colonization in Sediment Bars of a Regulated River, River Res. Appl., 31, 470-484, https://doi.org/10.1002/rra.2802, 2014.

Ayres, A., Gerdes, H., Goeller, B., Lago, M., Catalinas, M., García Cantón, Á., Brouwer, R., Sheremet, O., Vermaat, J., Angelopoulos, N., and Cowx, I.: Inventory of river restoration measures: effects, costs and benefits, eport REFORM-D1.4, 96 pp., available at: https://reformrivers.eu/ inventory-river-restoration-measures-effects-costs-and-benefits (last access: 13 June 2019), 2014.

Baptist, M. J., Penning, W. E., Duel, H., Smits, A. J. M., Geerling, G. W., Van der Lee, G. E. M., and Van Alphen, J. S. L.: Assessment of the effects of cyclic floodplain rejuvenation on flood levels and biodiversity along the Rhine River, River Res. Appl., 20, 285-297, 2004.

Basisadministratie adressen en gebouwen (National database addresses and buildings): http://www.kadaster.nl/BAG, last access: 28 November 2016 (in Dutch).

Becu, N., Perez, P., Walker, A., Barreteau, O., and Page, C. L.: Agent based simulation of a small catchment water management in northern Thailand: Description of the CATCHSCAPE model, Ecol. Model., 170, 319-331, https://doi.org/10.1016/S03043800(03)00236-9, 2003.

Bernhardt, E. S., Palmer, M. A., Allan, J. D., Alexander, G., Barnas, K., Brooks, S., Carr, J., Clayton, S., Dahm, C., Follstad-Shah, J., Galat, D., Gloss, S., Goodwin, P., Hart, D., Hassett, B., Jenkinson, R., Katz, S., Kondolf, G. M., Lake, P. S., Lave, R., Meyer, J. L., O’Donnell, T. K., Pagano, L., Powell, B., and Sudduth, E.: Synthesizing U.S. River Restoration Efforts, Science, 308, 636637, https://doi.org/10.1126/science.1109769, 2005.

Borowski, I.: Social Learning Beyond Multistakeholder Platforms: A Case Study on the Elbe River Basin, Soc. Nat. Resour., 23, 1002-1012, https://doi.org/10.1080/08941920903204307, 2010.

Brown, S., Nicholls, R. J., Hanson, S., Brundrit, G., Dearing, J. A., Dickson, M. E., Gallop, S. L., Gao, S., Haigh, I. D., Hinkel, J., Jiménez, J. A., Klein, R. J. T., Kron, W., Lázár, A. N., Neves, C. F., Newton, A., Pattiaratachi, C., Payo, A., Pye, K., Sánchez-Arcilla, A., Siddall, M., Shareef, A., Tompkins, E. L., Vafeidis, A. T., van Maanen, B., Ward, P. J., and Woodroffe, C. D.: Shifting perspectives on coastal impacts and adaptation, Nat. Clim. Change, 4, 752-755, https://doi.org/10.1038/nclimate2344, 2014.

Buijs, A. E.: Public support for river restoration. A mixedmethod study into local residents' support for and framing of river management and ecological restoration in the Dutch floodplains, J. Environ. Manage., 90, 2680-2689, https://doi.org/10.1016/j.jenvman.2009.02.006, 2009.

Buijse, A. D., Coops, H., Staras, M., Jans, L. H., Van Geest, G. J., Grift, R. E., Ibelings, B. W., Oosterberg, W., and Roozen, F.: Restoration strategies for river floodplains along large lowland rivers in Europe, Freshwater Biol., 47, 889-907, https://doi.org/10.1046/j.1365-2427.2002.00915.x, 2002.

Camporeale, C., Perucca, E., Ridolfi, L., and Gurnell, A. M.: Modeling The Interactions Between River Morphodynamics And Riparian Vegetation, Rev. Geophys., 51, 379-414, https://doi.org/10.1002/rog.20014, 2013.

Cheong, S.-M., Silliman, B., Wong, P. P., van Wesenbeeck, B., Kim, C.-K., and Guannel, G.: Coastal adaptation with ecological engineering, Nat. Clim. Change, 3, 787-791, https://doi.org/10.1038/nclimate1854, 2013.

DeConto, R. M. and Pollard, D.: Contribution of Antarctica to past and future sea-level rise, Nature, 531, 591-597, https://doi.org/10.1038/nature17145, 2016.

Deltaprogramma: Deltaprogramma 2017: Werk aan de delta, opgaven verbinden, samen op koers, Ministry of Infrastucture and Environment/Ministry of Economic Affairs, The Hague, the Netherlands, report dp2017, 99 pp., 2017. 
Deltares: Delft3D Flexible Mesh Suite: user manual, Deltares, Delft, the Netherlands, Manual version 1.1.0, 384 pp., 2016.

De Nooij, R. J. W., Lenders, H. J. R., Leuven, R. S. E. W., De Blust, G., Geilen, N., Goldschmidt, B., Muller, S., Poudevigne, I., and Nienhuis, P. H.: BIO-SAFE: assessing the impacts of physical reconstruction on protected and endangered species, River Res. Appl., 20, 299-313, 2004.

de Winter, R. C. and Ruessink, B. G.: Sensitivity analysis of climate change impacts on dune erosion: case study for the Dutch Holland coast, Climatic Change, 141, 685-701, https://doi.org/10.1007/s10584-017-1922-3, 2017.

Di Baldassarre, G., Viglione, A., Carr, G., Kuil, L., Yan, K., Brandimarte, L., and Blöschl, G.: Debates - Perspectives on socio-hydrology: Capturing feedbacks between physical and social processes, Water Resour. Res., 51, 4770-4781, https://doi.org/10.1002/2014WR016416, 2015.

Fliervoet, J. M. and van den Born, R. J. G.: From implementation towards maintenance: sustaining collaborative initiatives for integrated floodplain management in the Netherlands, Int. J. Water Resour. D., 33, 570-590, https://doi.org/10.1080/07900627.2016.1200962, 2017.

Fliervoet, J. M., Van den Born, R. J. G., Smits, A. J. M., and Knippenberg, L.: Combining safety and nature: A multi-stakeholder perspective on integrated floodplain management, J. Environ. Manage., 128, 1033-1042, https://doi.org/10.1016/j.jenvman.2013.06.023, 2013.

Frings, R. M., Berbee, B. M., Erkens, G., Kleinhans, M. G., and Gouw, M. J. P.: Human-induced changes in bed shear stress and bed grain size in the River Waal (The Netherlands) during the past 900 years, Earth Surf. Proc. Land., 34, 503-514, https://doi.org/10.1002/esp.1746, 2009.

Geerling, G. W., Kater, E., van den Brink, C., Baptist, M. J., Ragas, A. M. J., and Smits, A. J. M.: Nature rehabilitation by floodplain excavation: The hydraulic effect of 16 years of sedimentation and vegetation succession along the Waal River, NL, Geomorphology, 99, 317-328, https://doi.org/10.1016/j.geomorph.2007.11.011, 2008.

Giosan, L., Syvitski, J., Constantinescu, S., and Day, J.: Climate change: Protect the world's deltas, Nature, 516, 31-33, https://doi.org/10.1038/516031a, 2014.

Grothmann, T. and Reusswig, F.: People at Risk of Flooding: Why Some Residents Take Precautionary Action While Others Do Not, Nat. Hazards, 38, 101-120, https://doi.org/10.1007/s11069005-8604-6, 2006.

Hegnauer, M., Beersma, J., Van den Boogaard, H. F. P., Buishand, T. A., and Passchier, R. H.: Generator of rainfall and discharge extremes (GRADE) for the Rhine and Meuse basins, Deltares, Delft, the Netherlands, report 1209424-004, 84 pp., 2014.

Hering, D., Borja, A., Carstensen, J., Carvalho, L., Elliott, M., Feld, C. K., Heiskanen, A.-S., Johnson, R. K., Moe, J., Pont, D., Solheim, A. L., and de Bund, W. V.: The European Water Framework Directive at the age of 10: A critical review of the achievements with recommendations for the future, Sci. Total Environ., 408, 4007-4019, https://doi.org/10.1016/j.scitotenv.2010.05.031, 2010.

Hinkel, J., Lincke, D., Vafeidis, A. T., Perrette, M., Nicholls, R. J., Tol, R. S. J., Marzeion, B., Fettweis, X., Ionescu, C., and Levermann, A.: Coastal flood damage and adaptation costs under 21st century sea-level rise, P. NatL. Acad. Sci. USA, 111, 3292, https://doi.org/10.1073/pnas.1222469111, 2014.

Hübner, C., Ostrowski, M., and Haase, M.: nofdp IDSS-an open source flood control planning Decision Support System, in: 23rd International Conference on Informatics for Environmental Protection, Environmental Informatics and Industrial Ecology, Environmental Informatics and Industrial Environmental Protection: Concepts, Methods and Tools, 9-11 September 2009, Berlin, Germany, edited by: Wohlgemuth, V., Page, B., and Voigt, K., Shaker Verlag, Aachen, Germany, 87-96, 2009.

Jaspers, F. G. W.: Institutional arrangements for integrated river basin management, Water Policy, 5, 77-90, 2003.

Jong, P. and Brink, M. V. D.: Between tradition and innovation: developing Flood Risk Management Plans in the Netherlands, J. Flood Risk Manag., 10, 155-163, https://doi.org/10.1111/jfr3.12070, 2017.

Kernkamp, H. W. J., Van Dam, A., Stelling, G. S., and de Goede, E. D.: Efficient scheme for the shallow water equations on unstructured grids with application to the Continental Shelf, Ocean Dynam., 61, 1175-1188, https://doi.org/10.1007/s10236-011-04236, 2011.

Kind, J. M.: Economically efficient flood protection standards for the Netherlands, J. Flood Risk Manag., 7, 103-117, https://doi.org/10.1111/jfr3.12026, 2014.

Koopman, K. R., Straatsma, M. W., Augustijn, D. C. M., Breure, A. M., Lenders, H. J. R., Stax, S. J., and Leuven, R. S. E. W.: Quantifying biomass production for assessing ecosystem services of riverine landscapes, Sci. Total Environ., 624, 15771585, https://doi.org/10.1016/j.scitotenv.2017.12.044, 2018.

Le Bars, D., Drijfhout, S., and De Vries, H.: A high-end sea level rise probabilistic projection including rapid Antarctic ice sheet mass loss, Environ. Res. Lett., 12, 044013, https://doi.org/10.1088/1748-9326/aa6512, 2017.

Lenders, H. J. R., Leuven, R. S. E. W., Nienhuis, P. H., De Nooij, R. J. W., and Van Rooij, S. A. M.: BIO-SAFE: a method for evaluation of biodiversity values on the basis of political and legal criteria, Landscape Urban Plan., 55, 121-137, 2001.

Makaske, B., Maas, G. J., Van den Brink, N. G., and Wolfert, H. P.: The influence of floodplain vegetation succession on hydraulic roughness: is ecosystem rehabilitation in Dutch embanked floodplains compatible with flood safety standards?, Ambio, 40, 370376, 2011.

Marijnissen, R., Kok, M., Kroeze, C., and van Loon-Steensma, J.: Re-evaluating safety risks of multifunctional dikes with a probabilistic risk framework, Nat. Hazards Earth Syst. Sci., 19, 737756, https://doi.org/10.5194/nhess-19-737-2019, 2019.

Mechler, R. and Bouwer, L. M.: Understanding trends and projections of disaster losses and climate change: is vulnerability the missing link?, Climatic Change, 133, 23-35, https://doi.org/10.1007/s10584-014-1141-0, 2015.

Middelkoop, H.: Reconstructing floodplain sedimentation rates from heavy metal profiles by inverse modelling, Hydrol. Process., 16, 47-64, 2002.

Middelkoop, H. and Van Haselen, C. O. G.: Twice a river: Rhine and Meuse in the Netherlands, RIZA, Arnhem, the Netherlands, report 99.003, 1999.

Mostert, E., Pahl-Wostl, C., Rees, Y., Searle, B., Tàbara, D., and Tippett, J.: Social Learning in European River-Basin Management Barriers and Fostering Mechanisms from 10 River 
Basins, Ecol. Soc., 12, 19, https://doi.org/10.5751/es-01960120119, 2007.

Nardini, A. and Pavan, S.: River restoration: not only for the sake of nature but also for saving money while addressing flood risk. A decision-making framework applied to the Chiese River (Po basin, Italy), J. Flood Risk Manag., 5, 111-133, https://doi.org/10.1111/j.1753-318X.2011.01132.x, 2012.

Newman, J. P., Maier, H. R., Riddell, G. A., Zecchin, A. C., Daniell, J. E., Schaefer, A. M., van Delden, H., Khazai, B., O'Flaherty, M. J., and Newland, C. P.: Review of literature on decision support systems for natural hazard risk reduction: Current status and future research directions, Environ. Model. Softw., 96, 378-409, https://doi.org/10.1016/j.envsoft.2017.06.042, 2017.

Pardaens, A. K., Lowe, J. A., Brown, S., Nicholls, R. J., and de Gusmão, D.: Sea-level rise and impacts projections under a future scenario with large greenhouse gas emission reductions, Geophys. Res. Lett., 38, L12604, https://doi.org/10.1029/2011g1047678, 2011.

Postek, K., den Hertog, D., Kind, J., and Pustjens, C.: Adjustable robust strategies for flood protection, Omega, 82, 142-154, https://doi.org/10.1016/j.omega.2017.12.009, 2018.

Pratt Miles, J. D.: Designing Collaborative Processes for Adaptive Management Four Structures for Multistakeholder Collaboration, Ecol. Soc., 18, 5, https://doi.org/10.5751/ES-05709180405, 2013.

Robinson, C. J., Margerum, R. D., Koontz, T. M., Moseley, C., and Lurie, S.: Policy-Level Collaboratives for Environmental Management at the Regional Scale: Lessons and Challenges From Australia and the United States, Soc. Nat. Resour., 24, 849-859, https://doi.org/10.1080/08941920.2010.487848, 2011.

Rosenberg, S. and Margerum, R. D.: Landowner motivations for watershed restoration: lessons from five watersheds, J. Environ. Plann. Man., 51, 477-496, https://doi.org/10.1080/09640560802116962, 2008.

Samsura, D. A. A., van der Krabben, E., and van Deemen, A. M. A.: A game theory approach to the analysis of land and property development processes, Land Use Policy, 27, 564-578, https://doi.org/10.1016/j.landusepol.2009.07.012, 2010.

Sanjaya, K. and Asaeda, T.: Application and assessment of a dynamic riparian vegetation model to predict the spatial distribution of vegetation in two Japanese river systems, J. Hydro-Environ. Res., 16, 1-12, https://doi.org/10.1016/j.jher.2017.05.002, 2017.

Schielen, R. M. J. and Gijsbers, P. J. A.: DSS-large rivers: developing a DSS under changing societal requirements, Phys. Chem. Earth Pt. A/B/C, 28, 635-645, https://doi.org/10.1016/S14747065(03)00109-8, 2003.

Scholten, M. and Stout, J.: Dataprotocol Baseline 5.2.1, Rijkswaterstaat Waterdienst, Deltares, Lelystad, Delft, the Netherlands, 111 pp., 2013.

Scholten, M. and Stout, J.: Handleiding Baseline 5.2.3, Baseline 5.2.3 manual, Rijkswaterstaat Waterdienst/Deltares, Delft, the Netherlands, version 1.8, 121, 2014 (in Dutch).

Silva, W., Dijkman, J. P. M., and Loucks, D. P.: Flood management options for The Netherlands, International Journal of River Basin Management, 2, 101-112, https://doi.org/10.1080/15715124.2004.9635225, 2004.

Sloff, K., Van der Sligte, R., and Ottevanger, W.: Morfologische pakketsom Waal: morfologische effecten Ruimte-voor-de-Rivier maatregelen, Deltares, Delft, the Netherlands, report $1208454-$ 000, 188 pp., 2014.

Stanford, J. A., Ward, J. V., Liss, W. J., Frissell, C. A., Williams, R. N., Lichatowich, J. A., and Coutant, C. C.: A general protocol for restoration of regulated rivers, Regul. River., 12, 391-413, https://doi.org/10.1002/(sici)10991646(199607)12:4/5<391::aid-rrr436>3.0.co;2-4, 1996.

Stienstra, M. G.: Actualisatie bodemzoneringskaart, CSOAdviesbureau, Deventer, the Netherlands, report 09K206.R01/6, 47 pp., 2011.

Straatsma, M. W. and Kleinhans, M. G.: Flood hazard reduction from automatically applied landscaping measures in RiverScape, a Python package coupled to a twodimensional flow model, Environ. Model. Softw., 101, 102-116, https://doi.org/10.1016/j.envsoft.2017.12.010, 2018.

Straatsma, M. W., Bloecker, A. M., Lenders, H. J. R., Leuven, R. S. E. W., and Kleinhans, M. G.: Biodiversity recovery following delta-wide measures for flood risk reduction, Sci. Adv., 3, e1602762, https://doi.org/10.1126/sciadv.1602762, 2017.

Strager, M. P. and Rosenberger, R. S.: Incorporating stakeholder preferences for land conservation: Weights and measures in spatial MCA, Ecol. Econ., 57, 627-639, https://doi.org/10.1016/j.ecolecon.2005.05.015, 2006.

Tessler, Z. D., Vörösmarty, C. J., Grossberg, M., Gladkova, I., Aizenman, H., Syvitski, J. P. M., and Foufoula-Georgiou, E.: Profiling risk and sustainability in coastal deltas of the world, Science, 349, 638-643, https://doi.org/10.1126/science.aab3574, 2015.

Tockner, K. and Stanford, J. A.: Riverine flood plains: present state and future trends, Environ. Conserv., 29, 308-330, 2002.

UGRID Conventions: http://ugrid-conventions.github.io/ ugrid-conventions/, last access: 17 November 2016.

Van Alphen, J.: The Delta Programme and updated flood risk management policies in the Netherlands, J. Flood Risk Manag., 9, 310-319, https://doi.org/10.1111/jfr3.12183, 2016.

van Oorschot, M., Kleinhans, M., Buijse, T., Geerling, G., and Middelkoop, H.: Combined effects of climate change and dam construction on riverine ecosystems, Ecol. Eng., 120, 329-344, https://doi.org/10.1016/j.ecoleng.2018.05.037, 2018.

van Pelt, S. C., Beersma, J. J., Buishand, T. A., van den Hurk, B. J. J. M., and Kabat, P.: Future changes in extreme precipitation in the Rhine basin based on global and regional climate model simulations, Hydrol. Earth Syst. Sci., 16, 4517-4530, https://doi.org/10.5194/hess-16-4517-2012, 2012.

Van Stokkom, H. T. C., Smits, A. J. M., and Leuven, R. S. E. W.: Flood defense in the Netherlands a new era, a new approach, Water Int., 30, 76-87, 2005.

Van Velzen, E. H., Jesse, P., Cornelissen, P., and Coops, H.: Stromingsweerstand vegetatie in uiterwaarden, RIZA, Arnhem, the Netherlands, report 2003.028, 131 pp., 2003 (in Dutch).

Van Vuren, S., Paarlberg, A., and Havinga, H.: The aftermath of "Room for the River" and restoration works: Coping with excessive maintenance dredging, J. Hydro-Environ. Res., 9, 172-186, https://doi.org/10.1016/j.jher.2015.02.001, 2015.

Verbrugge, L. N. H., Ganzevoort, W., Fliervoet, J. M., Panten, K., and van den Born, R. J. G.: Implementing participatory monitoring in river management: The role of stakeholders' perspectives and incentives, J. Environ. Manage., 195, 62-69, https://doi.org/10.1016/j.jenvman.2016.11.035, 2017. 
Vorosmarty, C. J., McIntyre, P. B., Gessner, M. O., Dudgeon, D., Prusevich, A., Green, P., Glidden, S., Bunn, S. E., Sullivan, C. A., Liermann, C. R., and Davies, P. M.: Global threats to human water security and river biodiversity, Nature, 467, 555-561, https://doi.org/10.1038/nature09440, 2010.

Vrijling, J. K.: Probabilistic design of water defense systems in The Netherlands, Reliab. Eng. Syst. Safe., 74, 337-344, https://doi.org/10.1016/S0951-8320(01)00082-5, 2001.

Wahlstrom, M. and Guha-Sapir, D.: The human cost of weatherrelated disasters 1995-2015, CRED, UNISDR, Geneva, Switzerland, 30 pp., 2015.
Ward, J. V., Tockner, K., and Schiemer, F.: Biodiversity of floodplain river ecosystems: ecotones and connectivity, Regul. River., $15,125-139,1999$.

Ward, J. V., Tockner, K., Uehlinger, U., and Malard, F.: Understanding natural patterns and processes in river corridors as the basis for effective river restoration, Regul. River., 17, 311-323, https://doi.org/10.1002/rrr.646, 2001.

WEF: Global Risks Report 2018, 13th edition, World Economic Forum, Geneva, Switzerland, 80 pp., 2018. 